\title{
Baimès koncepcija ir emocijos Lietuvos užsienio politikoje
}

\begin{abstract}
Šiame straipsnyje pristatoma baimès sampratos refleksija tarptautinių santykių ir užsienio politikos teorijose. Tekste iš pradžių aptariama baimès fenomeno ir racionalaus elgesio sampratos, akcentuojant, jog baimès samprata, priešingai nei anarchijos, tarptautinių santykių teorijoje neturi emocinio krūvio. Apžvelgus emocijų veiksnị tarptautinių santykių ir užsienio politikos teorijoje siūloma sugrąžinti baimès kategorijai reikšmingą emocinị krūvị. Darbe akcentuojama, jog baimè (traktuojant ją kaip emociją) gali turèti ir tarptautinę sistemą ardančią ir tarptautinę komunikaciją trikdančią funkciją. Ši emocionalizuota grèsmès ir baimès suvokimo samprata (darbe ịvardyta kaip para bellum įsitikinimų sistema) dèl savo intensyvaus emocinio krūvio ir valstybès vidaus veiksnių dominavimo įtvirtinant baimès jausmą skiriasi nuo kitų baimès suvokimo tipų galios asimetrijos (realizmas) ir identitetų asimetrijos (liberalizmas, konstruktyvizmas). Straipsnyje šie baimès suvokimo tipai yra traktuojami kaip socialiniai įsivaizdavimai, per laiką vienas kitą keičiantys ar papildantys. Trečioji straipsnio dalis skiriama Lietuvos užsienio politikos idejų analizei. Darbe analizuojama Lietuvos regiono lyderès idejja. Teigiama, jog ji buvo neracionali, nes paremta baimès emocijos faktoriumi. Taip pat pateikiamos įžvalgos ir siūlymai skirti naują besiformuojantị Lietuvos užsienio politikos etapą (nuo 2014 m. Krymo okupacijos), kuriame, kaip ir regiono lyderés koncepte ir priešingai nei kitose Lietuvos užsienio politikos etapuose, dominuoja baimès emocija. Straipsnis užbaigiamas probleminiu klausimu - ar Lietuvos užsienio politikoje įsitvirtinanti nauja idejinè kryptis netaps nelanksčia, para bellum logika paremta įsitikinimų sistema, ateityje trikdysiančia optimalų užsienio politikos formavimą.
\end{abstract}

\section{Ivadas}

Užsienio politikos, kaip proceso ir kaip mokslinio objekto, ribas nèra lengva aiškiai apibrežti. Užsienio politika - tiek vidaus, tiek tarptautinị lygmenị apimanti sritis. Tai, viena vertus, šią politikos mokslų sritị daro kompleksinę ir reikalaujančią integruoto socialinių mokslų (politikos, geopolitikos, tarptautinių santykių, ekonomikos, psichologijos, sociologijos ir pan.) studijavimo, kita vertus, toks kompleksiškumas aštrina nesutarimus ne tik dèl to, kaip tirti

\footnotetext{
* Benas Brunalas - Vytauto Didžiojo universiteto Politikos mokslų ir diplomatijos fakulteto doktorantas; Mykolo Romerio universiteto Politikos ir vadybos fakulteto lektorius. Adresas korespondencijai: Valakupių 5, LT-10101 Vilnius, tel. (8 5) 274 0611; el.p. benas.brunalas@gmail.com.
} 
užsienio politikos problemas, bet ir ginčus dèl to, kas yra svarbiausios užsienio politikos problemos, kaip apibrèžiamos ir kaip turi būti apibrèžtos pagrindinès teorijų sąvokos. Viena tokių sąvokų ir socialinių būsenų yra baimè.

Baimè tarptautinių santykių teorijoje yra svarbus, nacionalinių valstybių elgseną paaiškinti padedantis veiksnys. Baimę realistų priimta traktuoti kaip natūralią reakciją i ̇anarchišką tarptautinių santykių sistemą. Tikima, jog pavojingoje, „džiungles“ primenančioje pasaulio tvarkoje Kito baimè gali padèti objektyviai ịvertinti situaciją ir, kadangi baimè kyla dèl tarptautinès sistemos struktūros priežasčių, formuoti racionalią valstybès užsienio politiką. Kitaip tariant, baimé - tai paskata racionaliai ir pragmatiškai valstybès elgsenai. Liberalioje tarptautinių santykių perspektyvoje baimès priežastys yra tapatybių kaitos dinamika. Baimé kyla, kai Kitas tolsta nuo $A s ̌$ ar ignoruoja universalias liberalias vertybes ir siekia revizuoti status quo. Šiuo požiūriu liberalų idèjos artimos konstruktyvistams, kurie baimę traktuoja kaip priemonę auditorijai pateikti (saugumizacijos aktas) ir išspręsti (desaugumizacijos aktas) nacionalinio saugumo problemas. Kitaip tariant, konstruktyvistams Kito baime atlieka svarbią socialinio statymo (tapatybès konstravimo) ir socialinio igalinimo (problemų sprendimo) funkciją.

Šios baimès sampratos kiekvienoje minètoje teorijoje yra svarbūs tarptautinių procesų aiškinimo ir supratimo konstruktai, nuo kurių priklauso tiek mokslinių problemų nustatymas, tiek jų sprendimo strategijos. Tačiau tokios sąvokų apibrèžtys, baimei priskiriant vien tik struktūrinę ar tapatybinę prigimtị, turi savo kainą - socialinès realybès ir socialinių procesų supaprastinimą. Tai savo ruožtu grasina, jog socialinių procesų dinamika ir jos varomosios jègos nebus atskleistos ar pakankamai tiksliai ịvertintos. Pavyzdžiui, realistams valstybès baimès priežastys visada bus išorèje (tarptautinèje struktūroje) ir visada susijusios su iš prigimties blogos valstybès galios parametrų didejjimu. Todèl baimé visiems ir visada bus vienoda, nepriklausoma nuo subjektyvių tarptautinio subjekto savybių.

Galima pastebèti, jog pristatytose baimès sampratose neatsiskleidžia arba beveik neatsiskleidžia emocinè baimès fenomeno prigimtis. Kitaip tariant, ir realistai, ir liberalai operuoja ne emocine (iracionalia), bet pragmatiška (racionalia) baimès samprata. Tiek vienoje, tiek kitoje paradigmoje baimé net turi savotišką pozityvią funkciją: teisingai ịvertinti tarptautinę aplinką (realizmas) arba konstruoti ir plèsti (išskiriant arba ịraukiant grèsmingus Kitus) tapa- 
tumus (liberalizmas, konstruktyvizmas)1.

Šiame darbe reflektuojama baimès sąvoka, „sugrąžinant“ jai iracionalų emocinị prasmès krūvị. Tokia baimès emocionalizacija darbe traktuojama kaip euristinè priemoné, padedanti geriau suprasti ir paaiškinti baimès (kaip emocijos) fenomeno ịtaką tarptautiniams santykiams ir užsienio politikos formavimo procesams. Straipsnyje teigiama, jog baimé nebūtinai yra išorinio pobūdžio: tarptautinès sistemos (galios asimetrijos) ar tapatybès struktūros (identitetų asimetrijos) priežastis. Baimé gali būti ir pasekmè valstybès viduje esančios įsitikinimu sistemos (angl. belief system), kuri grèsmes ir baimes atpažịsta veikiau dèl savo ịsitikinimu sistemos struktūrinio turinio, o ne dèl išorinių tarptautinès aplinkos priežasčių. Šioje sampratoje emocijos veikia kaip baimę generuojantis ir palaikantis veiksnys, nebūtinai susijęs su tikrosiomis (objektyviomis) baimès priežastimis (baimès šaltiniu). Tokiu būdu baimès pasekmes tarptautinių santykių kontekste galima vertinti kaip destruktyvias, veikiau ardančias nei formuojančias tarptautines sistemas.

Taigi darbe, jungiant skirtingas tarptautinių santykių paradigmas (realizmas, liberalizmas, konstruktyvizmas, psichologinès krypties užsienio politikos teorijos), išskiriami trys idealūs grèsmių ỉsivaizdavimų tipai, kurie gali paaiškinti baimès atsiradimo, vyravimo valstybių užsienio politikos naratyvuose priežastis bei pasekmes. Tokia teorinè refleksija sudaro galimybes pateikti baimès ir grèsmių aiškinimo modelĭ, neapsiribojant vienos teorijos terminija ir analizès logika (realybès redukcijos mažinimo momentas), ir praplečia baimès sampratą (sugrąžinant emocionalumą), leidžiančią naujai ịvertinti tiek užsienio politikos teoriją, tiek praktiką.

Pateiktos teorinès j̨žvalgos pasitelkiamos analizuojant Lietuvos užsienio politikos etapus. Straipsnyje teigiama, jog nuo $2014 \mathrm{~m}$. galima skirti naujai besiformuojantị Lietuvos užsienio politikos etapą, kuris savo idẻjine ir tapatybine struktūra artimas 2004-2009 m. formuotai Lietuvos regiono lyderès užsienio politikos vizijai. Darbe akcentuojama, jog prasidejusị ir 2004-2009 m. vyravusị Lietuvos užsienio politikos etapą vienija socialineje struktūroje ịsitvirtinęs baimès jausmas, kylantis kaip baime paremtos įsitikinimu sistemos padarinys. Šie du Lietuvos užsienio politikos etapai darbe traktuojami kaip emocinès, todèl nepragmatinès valstybès politikos pavyzdžiai.

\footnotetext{
${ }^{1}$ Realistų atžvilgiu baimès racionalus ịsivaizdavimas kyla dèl jų siaurai apibrèžtos socialinès realybès ir specifiškai tipizuotos anarchijos; liberalioje ir konstruktyvistineje teorijoje baimès (kaip paskatos) pozityvus vaizdavimas gali būti priežastis to, jog tiesiog nę̨vertinami psichologiniai grèsmès suvokimo ir reakcijos ị grèsmę aspektai.
} 


\section{Racionali valstybès elgsena tarptautinių santykių teorijoje}

Realizmas pelnytai gali būti laikomas viena svarbiausių ar net kertinių tarptautinių santykių teorijų. Jos koncepciniu pagrindu tarptautiniai santykiai formavosi kaip atskiras, savo objektą ir metodus turintis socialinis mokslas. Taip pat didžiulè realizmo mokslinè ir filosofine ittaka užsienio politikos tyrimams. Realistai kritikavę savo pirmtakus idealistus ragino tarptautini elgesị aiškinti nacionalinių interesų požiūriu, neatsižvelgiant ị tautų moralines nuostatas, puoselëjamas viltis ar nuostatas ir viltis, kurių turi stebètojai². Todèl, Hanso Morgenthau manymu, realistų siekis yra atskirti tiesą nuo nuomonès tai, kas objektyviai ir racionaliai teisinga ir patvirtinta duomenų, nuo to, kas yra tik subjektyvus vertinimas, nesusijęs su faktais ir ịkvèptas prietarų bei įnoringo mąstymo ${ }^{3}$. Taigi realistas suvokia žmogaus ir valstybès prigimtį tokią, kokia ji yra, o ne tokią, kokia turètų būti, ir istorinius ịvykius regi tokius, kokie jie yra, bet ne kokie turèjo būti.

Galima sakyti, jog realistų pretenzija buvo pateikti mokslinị, pragmatinị ir racionalų tiek valstybès elgsenos aiškinimo, tiek praktinès politikos vystymo žemèlapị. Tai savotiškas racionalios ir pragmatinès valstybės elgsenos charakterizavimas tarptautineje politikoje. Trumpai tariant, racionali valstybès užsienio politika ịmanoma tik tada, jei objektyviai (be ideologijos, prietarų, įnoringo mąstymo, stereotipų) įvertinamos tarptautinès sistemos aplinkybès ir tik prie jų prisitaikius igyvendinama politika. Todèl, pavyzdžiui, idealistų visuotinès taikos siekis buvo ne kas kita, kaip kova su realybe, tad ne tik neracionalus ir nepragmatiškas, bet ir neįmanomas.

Realistams objektyvus aplinkos suvokimas nèra aporija, nes tikima, jog bėgant metams politiką valdantys dèsniai nepakito. Jie, anot Morgenthau, leidžia realistui tiksliai nurodyti valstybès vadovui, kaip racionaliai pasielgti susiklosčius įvairioms aplinkybėms.

Realizmo teorineje perspektyvoje akcentuojami universalūs politiniai suvaržymai, kuriuos lemia žmonių egoizmas ir tarptautinès vyriausybės nebuvimas $^{4}$. Užsienio politikos aiškinimui tai labai svarbūs veiksniai. Kiekviena valstybè visais laikais turẻjo reaguoti $\mathfrak{i}$ šias universalias aplinkybes, taigi galima kalbèti apie tam tikrus dėsningumus ir bendras, visoms valstybėms vienodas

\footnotetext{
${ }^{2}$ Martin H., Smith S., Tarptautiniai santykiai: aiškinimas ir supratimas. Vilnius: Tyto alba, 1998, p.19.

${ }^{3}$ Morgenthau H., Politika tarp valstybių: kova dè galios ir taikos. - Vilnius: Margi raštai, 2011.

${ }^{4}$ Burchill, S., Linklater, A., Devetak, R., Donnelly, J., Paterson, M., Reus-Smit, C., True, J., eds. Theories of International Relations, 3rd. edition. New York, USA: Palgrave Macmillan, 2005, p. 30.
} 
paskatas, kas iš esmès nulemia tai, kaip valstybė elgsis grèsmès akivaizdoje (pavyzdžiui, balansuos grèsmę arba šliesis prie grèsmès (angl. bandwagoning), sieks neutraliteto ${ }^{5}$ ). Taigi Kennetho Waltzo neorealistineje sampratoje analitinis dėmesys sukoncentruotas ị tarptautinès sistemos struktūrą. Siekiant suprasti atskirų valstybių elgseną, reikia pirmiau suprasti tarptautinę sistemą, o ne konkrečių valstybių užsienio politikos peripetijas. Valstybių veiksmus lemia ir subordinuoja nuasmeninta tarptautinių santykių sistema ${ }^{6}$.

Prioritetizuodamos makro lygmens procesus neorealistinès paradigmos užsienio politikos tyrimuose apeina ir reikšmingo demesio neskiria valstybių elitui, lyderiams ir jų savybėms, kurios dažnai gali būti išskirtinai retorinès, emocinès ar asmeniškos. Svarbiausia yra anarchinè tarptautinè sistema, kuri spausdama valstybes verčia išlikimą laikyti pagrindiniu užsienio politikos tikslu. Tokiu būdu nacionalinis interesas yra susietas su valstybès saugumo ir galios siekiu anarchinèje tarptautinių santykių aplinkoje. Bandymas ignoruoti šią realybę (ignoruoti anarchijos prigimtį) yra tolygus rizikai, jog sisteminés jeggos tave nubaus arba net visiškai sunaikins. Būtent šiame permanentinę grésmę ịvardijančiame loginiame apibendrinime slypi realizmo baimes, kaip racionalios paskatos, samprata. Pripažinus, jog valstybès elgesys yra tik pasekmè, o anarchinè tarptautiné sistema - priežastis, kvestionuoti baimès ar nepasitikejimo Kitu racionalumą neverta. Kitaip tariant, baimé - tai sisteminis (todèl racionalus) fenomenas.

Tačiau dèl to (neo)realizmas gali būti kaltinamas dèl pernelyg didelio redukcionalumo. Valstybè realistiniame aiškinime nuo kitos valstybès skiriasi tik savo turima galia, o tarptautinè sistema - savo poliškumu. Taigi ignoruojama daugybẻ kitų socialiniam pasauliui būdingų paskatų - kultūra, istorinė atmintis, vyraujančios tradicijos ir pan. Taip realistai objektyviai elgsenai palieka tik labai ribotą erdvę - pripažinus baimès racionalumą, i j ją reaguoti galios balansavimu, prisišliejimu arba neutralumu. Jei bandytume suabejoti šia logika, teigdami, jog tai tik viena iš realybès variacijų, kad ne tik gali, bet ir susiklosto kitais dèsningumais paremtos tarptautinès sistemos (nebūtinai baimès racionalumu grịstos sistemos), realizmo teorija subyrètų, o realistų racionalios valstybės elgsenos samprata primintų išankstinị nusistatymą ar prietarą.

\footnotetext{
${ }^{5}$ Waltz K., Theory of International Politics, New York: Random House, 1979.

${ }^{6}$ Siekiant suprasti ir aiškinti užsienio politiką realistiškai pirmiausia reikia ką nors pasakyti apie pačią struktūrą. Pavyzdžiui, kokios sąlygos vyrauja konkrečioje struktūroje: nuo to, ar sistema yra vienpolè, dvipole ar daugiapolè, priklausys ir joje esančių valstybių elgesys. Kitaip tariant, tikima, jog vienmatis procesų aiškinimas (galios, galios pasiskirstymo) veiks nepriklausomai nuo kitų faktorių (laikas, erdvė, kultūra) pokyčiu
} 
Apibendrinant galima daryti išvadą, jog realistų racionalios valstybės politikos aiškinimą galima suprasti kaip pragmatinị valstybès sąveikavimą su aplinka, t. y. atsižvelgiant $\mathfrak{i}$ aplinkos ypatumus. Tai puikiai iliustruoja Morgenthau, Waltz ir kiti realistai akcentuodami, jog, pavyzdžiui, idealizuotas pasaulio ìsivaizdavimas gali kainuoti labai brangiai - nepriklausomybę. Šiame darbe sutinkama su realistų siūlytu racionalios elgsenos, kaip objektyvaus tarptautinès sistemos aplinkybių ịvertinimo, apibrèžimu. Tačiau prieštaraujama, jog būtent realistų nurodytos pamatinès jègos - konfliktiška anarchija, egoistiška žmogaus prigimtis - yra universalijos, kurios nepriklausomai nuo laiko ir erdvès pokyčių vadovui nurodys, kaip elgtis racionaliai.

Kitaip tariant, nors realistų aiškinimas ir yra racionalus, jis nèra realus ${ }^{7}$. Tarptautinių santykių realizmo teoriją dèl jos koncepcinio siaurumo galima suvokti veikiau kaip lokalaus realizmo teoriją. Vadovaudamiesi griežtai struktūrine mąstymo logika bei universalijomis tarptautinių santykių realistai bando realybę sutraukti ị vieną schemą. Pagal juos valstybių interesus (tikruosius interesus), tarsi monolitinio ir nuspejjamo politinio subjekto interesų algoritmus, mes galime žinoti net neišstudijavę tos valstybès istorijos ar kultūros. Tarptautinè aplinka, anot jų, vienkryptè, nuspejjama, paremta tais pačiais dèsningumais. Tai atitinkamai riboja aiškinimo potencialą. Pragmatiniam požiūriui aktualus istorinis laikas su esamomis taisyklèmis, normomis ir vertybèmis. Taigi teorinès schemos, metodologinis dogmatizmas, prisirišimas prie vienos tiesos ar vieno aiškinimo socialiniuose moksluose gali ne tiek atspindèti, kiek prokrustiškai issprausti realybę ì siaurus supratimo rèmus, homogenizuoti ir pernelyg supaprastinti žmogaus motyvacijos šaltinius.

Nedo Lebowo pasiūlyta idealiais tipais paremta tarptautinių santykių teorija iš dalies bando spręsti šią problemą. Teigdamas, jog konvencinès tarptautinių santykių teorijos, būdamos orientuotos ị struktūrinị, o ne procesinị aiškinimą, negali suvokti tikrųjų socialinių procesų priežasčių. Todėl autorius savo teorijoje, išskirdamas idealius tarptautinès kultūros tipus, pirmenybę suteikia procesui, o ne struktūrai, pokyčiams, o ne stabilumui ir taip siekia koncentruotis ị dinaminių procesų, keliančių tarptautinès sistemos pokyčius, analizę. Lebowas savo teoriją grindžia realybėje neegzistuojančių idealių struktūrinių tipų skyrimu, leidžiančiu, viena vertus, neprisirišti prie vienos universalios paskatos (galios siekimas, turto siekimas, garbės siekimas), kita vertus, sudaro

\footnotetext{
${ }_{7}^{7}$ Darbe samprata „realus“ suprantama sąvokos „pragmatiškas“ prasme. Pragmatiška ir reali teorija būtinai turi būti lanksti savo tiriamo objekto atžvilgiu.

${ }^{8} \mathrm{~N}$. Lebow išskiria idealius kultūrinius tarptautinès sistemos tipus - proto (angl. reason), garbès (angl. spirit), troškimo (angl. appetite) ir baimès (angl. fear).
} 
galimybes stebèti ir ịvertinti struktūrinius pokyčius (idealių tipų dinamiką)9. Tai, anot Lebowo, leidžia pateikti ne momentinį tarptautinių santykių aiškinimą. Kitaip tariant, autorius akcentuoja, jog apie tarptautinę sistemą galima pasakyti kur kas daugiau nei, pavyzdžiui, manytų Waltzas ${ }^{10}$. Taip pat Lebowas reflektuoja realistų apibrèžtos baimès (kaip racionalios paskatos) sampratą, ją (kaip emociją ir tarptautinès politikos struktūras griaunantị veiksnị) atskirdamas nuo kitu paskatų. Tokia baimés fenomeno refleksija gali būti suvokiama kaip savotiškas realizmo teorijos falsifikavimo projektas. Jei, pavyzdžiui, paaiškètų, jog baime nèra ar ne visada yra racionali paskata realizmo teorijai, kalbant Thomo Kuhno terminais, susidarytų anomali situacija. Kita vertus, baimés fenomeno refleksija įdomi ir vertinga siekiant geriau suvokti užsienio politikos formavimo ir igyvendinimo procesus, kurių aiškinimui realistai padarè didelę ịtaką primesdami tiek sąvokas, tiek tyrimo logiką ir formuojamas problemas. Atsižvelgiant ị visa tai toliau apžvelgiami baimés fenomeno tyrimai ir analizuojami baimès, kaip emocijos, kilimo šaltiniai.

\subsection{Emocijų samprata socialinių mokslų tyrimuose}

Emocijos, kaip iracionalią elgseną skatinančios paskatos, samprata tradiciškai apibrěžiama pirmajame (individo) analizès lygmenyje. Individo analizès lygmuo orientuojasi ị žmogaus (pavyzdžiui, lyderio) elgseną, charakterị, asmenines savybes ir $\mathfrak{i}$ to įtaką priimamiems ir užsienio politiką veikiantiems sprendimams. Užsienio politikos dinamika ir jos igyvendinimas aiškinamas per individualių asmenų ar grupių sąveikos procesus. Tai tarsi bandymas išsivaduoti iš sisteminio politinių procesų aiškinimo, kuris ịvykusius ar ịvyksiančius procesus dažnai regi kaip neišvengiamus ir užprogramuotus ${ }^{11}$. Tai keičia ir racionalios elgsenos užsienio politikoje sampratą. Struktūriniu lygmeniu (objektyvios paskatos) užsienio politika yra racionali, jei laikomasi socialinio pasaulio dèsningumų (anarchija, galia ir saugumas), tai individų analizès lygmeniu (subjektyvios paskatos) atsargiai žvelgiama ị teiginị, jog užsienio politikos sprendimų prièmimas yra (gali būti) racionalus procesas. Teiginys

\footnotetext{
${ }^{9}$ Lebow N. R., A Cultural Theory of International Relations, Cambridge: Cambridge University Press, 2008. ${ }^{10}$ Viena vertus, tai primena tai, ką kalbejo Wendtas, išskyręs tris anarchijos tipus (Hobbeso, Locke ir Kanto). Tačiau tarp šių autorių esamą reikšmingų skirtumų - vienas jų yra baimès konceptualizavimas. Lebowas baimę apibrèžia kaip emociją, kuri veikiau veikia kaip tarptautinę struktūrą destabilizuojantis nei struktūrą kuriantis ir palaikantis veiksnys. Tai Lebowo konceptualizuotą baimès kultūrą atskiria tiek nuo Wendto apibrèžto Hobbeso anarchijos tipo, tiek nuo realistų tarptautinès sistemos ịsivaizdavimo.

${ }^{11}$ Byman L. D., Pollack, M. K., "Let Us Now Praise Great Man”, International Security, Vol. 25 No. 4, MIT, Spring 2001. p. 145.
} 
argumentuojamas tuo, jog užsienio politikos srities sprendimai dažnai lemti subjektyvių gyvenimo faktorių (asmeninè patirtis, išankstinès nuostatos, ịsitikinimai ${ }^{12}$ ), prieštaraujančių tradiciškai suprantamai racionalaus pasirinkimo sampratai ${ }^{13}$. Šios iracionalios elgsenos paskatos „pasitelkiamos“, kai, kaip teigia Georgas Sorensenas ir Robertas Jacksonas, individas nepajėgus aprobuoti ir issisavinti visos reikšmingos informacijos ${ }^{14}$. Jerelas A. Rossatis ${ }^{15}$ teigia, jog šios subjektyvios paskatos būdingos ne vien tik individams, bet taip pat yra ideologinių nuostatų, i̦sitikinimų sistemų, grupinių supratimo modelių svarbi dalis. Taigi iracionalios kognityvinès ir operacinès schemos gali veikti ne tik pavienius individus, bet ir plačias socialines bendruomenes.

Mokslininkai pastaraji dešimtmeti vertinantys emocijų ịtaką tarptautinès politikos procesams laikosi pozicijos, jog emocijų fenomeno ontologija negali būti redukuota iki psichologijos ir fiziologijos ${ }^{16}$. Ema Hutchison ir Rolandas Bleikeris savo straipsnyje Theorizing emotions in world politics aptaria fundamentalų emocijų sampratos klausimą. Autoriai prieina prie išvados, jog emocijos visgi nèra vien tik individualus fenomenas. Emocijos taip pat turi aiškų socialinị krūvị, todèl emocijos reikalauja ir politinio (ne tik psichologinio ar neurologinio) teoretizavimo ${ }^{17}$. Kitaip tariant, autoriai pabrèžia, jog emocijos peržengia fiziologijos ir psichologijos ribas ir gali būti traktuojamos kaip socialinis ir normatyvinis reiškinys ${ }^{18}$. Mokslininkai teigia, jog tai, ką žmonès jaučia ir išreiškia fiziologiškai kaip emociją, yra socialinių ir kultūrinių procesų susidūrimo rezultatas ${ }^{19}$. Baimès, pykčio, pasitikejjimo, empatijos išraiška labai priklauso nuo kultūrinio konteksto, kuris emocijas visuomenei daro prasmingas ir priimtinas ${ }^{20}$. Tai pagrindžia psichologo Williamo Jameso darbai, pabrèžę socialinių ir kultūrinių veiksnių svarbą emocijų formavimuisi ir raiškai ${ }^{21}$.

Apie tai, kad emocijos yra kultūrinis fenomenas, kalbėjo nemažai moks-

\footnotetext{
${ }^{12}$ Rosati J. A., „The Power of Human Cognition in the Study of World Politics“, International Studies Review, 2(3), 2000, p. 45-79.

${ }^{13}$ Rourke, J. International Politics on the World Stage 12th edition. New York, USA: McGraw-Hill Higher Education, 2007, p. 65-72.

${ }^{14}$ Jackson R., Sorensen G., Introduction to International Relations Theories and Approaches, NY:Oxford University Press, 2007, p. 235.

${ }^{15}$ Rosati J.A., „The Power of Human Cognition in the Study of World Politics“, International Studies Review, 2(3), 2000.

${ }^{16}$ Mercer J., „Feeling Like a State: Social Emotion and Identity“, International Theory 6(3), 2014.

${ }^{17}$ Hutchison E., Bleiker R., „Theorizing emotions in world politics“, International Theory, Volume 6(3), 2014, p. 497.

${ }^{18}$ Ten pat, p. 504.

${ }^{19} \mathrm{~T}$ en pat, p. 505

${ }^{20}$ Ten pat p. 504.

${ }^{21}$ James W., "What is an Emotion?" Mind, Vol. 9, No. 34, Oxford University Press on behalf of the Mind Association, 1884.
} 
lininkų ${ }^{22}$. Pavyzdžiui, Bially Mattern teigia, jog emocijos visada yra kultūrinès ir kolektyvinès ${ }^{23}$. Khaledas Fattahas ir Karina Fierke pabrèžè, jog emocijos tai socialiai prasmingos ekspresijos, kurios priklauso nuo vyraujančiu papročių ir nusistovejjusių normų ${ }^{24}$. Emocijos, argumentuoja Hutchison ir Bleiker, dalyvauja individų ir bendruomenių socializacijos procesuose ${ }^{25}$. Jonathanas Merceris atkreipe dėmesị ị emocijų funkciją konstruojant identitetus ${ }^{26}$. Keliuose savo darbuose autorius pastebejo, jog kuo labiau žmonès yra susaistyti kolektyvinių ịsitikinimų ir bendro identiteto, tuo labiau jie dalijasi bendromis emocijomis $^{27}$.

Taigi identitetas ir jo konstravimas yra terpé, kurioje emocijos tampa reikšmingos ar net vienas iš esminių komponentų ${ }^{28}$, pavyzdžiui, kaltès emocija Vokietijos ir Vakarų valstybių identitetuose ${ }^{29}$. Tačiau, reikia pabrèžti, kad emocijos kuriant identitetą gali būti suvoktos kaip specifinis ir kol kas nepakankamai ivvertintas faktorius. Konstruktyvistai kalbėdami apie identiteto konstravimą dažnai svarbiausiomis identiteto sudedamosiomis dalimis laiko kultūrą, istoriją, religiją, priklausymą aljansams ir pan. Tai statiški kintamieji. O emocijoms, kaip specifinèms socialinėms reakcijoms ar jausminèms manifestacijoms, galinčioms sukelti visuomenèje didžiulį nepasitenkinimą, įniršį ar baimę, nèra skiriama dèmesio.

Šiame kontekste Hutchison akcentavo, jog konstruojant identitetą emocijos igauna specifinę funkciją - jos veikia kaip savotiškas mediumas ir bendruomenès tvirtinimo priemoné, siekiant ijungti tuos narius, kurie neturi tiesioginès sąsajos su konkrečiai bendruomenei ir jos identitetui svarbiais (pavyzdžiui, istoriniais) ívykiais ${ }^{30}$. Taigi emocijos dèl paties apeliavimo ị jausmus

\footnotetext{
${ }^{22}$ Pavyzdžiui, Abu-Lughod L., Lutz C. "Introduction: Emotion, Discourse, and the Politics of Everyday Life", Language and the Politics of Emotion, edited by Lila Abu-Lughod, and Catherine A. Lutz, 1-23. Cambridge: Cambridge University Press, 1990.

${ }^{23}$ Mattern B., "A Practice Theory of Emotion for International Relations", International Practices, ed. Adler E., Cambridge: Cambridge University Press, 2011.

${ }^{24}$ Khaled F., Fierke K. M., "A Clash of Emotions: The Politics of Humiliation and Political Violence in the Middle East”, European Journal of International Relations 15(1) 2009.

${ }^{25}$ Hutchison E., Bleiker R., „Theorizing emotions in world politics“, International Theory, Volume 6(3), 2014 , p. 507.

${ }^{26}$ Mercer J., „Feeling Like a State: Social Emotion and Identity“, International Theory 6(3), 2014.

${ }^{27}$ Mercer J., „Emotional Beliefs“, International Organization 64(1), 2010.

${ }^{28}$ Pavyzdžiui, Merceris tvirtina, jog emocijos kuriant identitetą yra vienas esminių komponentų. Grupès identitetas neegzistuotų nesant emocinio krūvio. Atpažinimas be emocijų - šaltas, neutralus ir silpnas aplinkos stebejimas, neprovokuojantis jokio veiksmo (manifestacijos). Mercer J., "Feeling Like a State: Social Emotion and Identity", International Theory 6(3), 2014.

${ }^{29}$ Branscombe N. R., Doosje B. (eds.). Collective Guilt: International Perpectives. Cambridge. Cambridge University Press, 2004.

${ }^{30}$ Hutchison E., „Trauma and the Politics of Emotions: Constituting Identity, Security and Community after the Bali Bombing“, International Relations 24/1, 2010.
} 
gali tapti svarbiausia jẻga, verčiančia individus ir bendruomenes tapatintis su kuo nors ar net mirti dẻl ko nors. Pavyzdžiui, socialinių neramumų, revoliucijų, karų, katastrofų periodais individai ar bendruomenès gali staiga susitapatinti su iki tol svetimais, nepažịstamais identitetais arba, priešingai, išstumti iki tol Mes kategorijai priklaususias tapatybes.

Taigi ne tik patirtis ar atmintis, bet ir jos raiška $\mathrm{a}^{31}$, apeliuojant $\mathrm{i}$ jausmus, gali veikti (teigiamai ar neigiamai, konstruktyviai ar destruktyviai) socialines bendruomenes. Kitaip tariant, emocijų fenomeno įvedimas, analizuojant socialinių struktūrų elgsenos ir identiteto dinamiką, verčia kelti papildomus klausimus: koks bendruomenėje randamų stereotipų, kolektyvinių atsiminimų, isitikinimu sistemu raiškos ir manifestacijos vaidmuo identiteto konstravimo ir politikos formavimo procese.

Apibendrinant galima teigti, jog emocijos yra diskurse isitvirtinusios, nuo istorinių, religinių, kultūrinių ir kitų socialinių veiksnių priklausančios kognityvinès - manifestacinès schemos. Šios schemos apibrèžia socialinių bendruomenių elgseną, tačiau, priešingai nei realistų koncepcijoje, generuojamos elgsenos paskatos yra subjektyvi interpretacija, apeliuojant $\mathfrak{i}$ jausmus, o ne objektyvus kintamųjų lyginimas ir vertinimas aktualioje aplinkoje (pavyzdžiui, galios). Todèl nors pati emocinè reakcija gali būti pagrịsta, tačiau jos išlaikymas ir itvirtinimas socialiniuose diskursuose gali lemti situaciją, jog emocija aktyvi vien dèl likusios, manifestacinių procesu palaikomos inercijos. Taip emocinès reakcijos šaltiniu tampa ne objektyvus dirgiklis, bet pati emocinè manifestacija. Tad visuomenejje kilusių pažeminimo (Paulas Saurette ${ }^{32}$ ), keršto (Gadis Heimannas ${ }^{33}$ ), nostalgijos (Mira Sucharova ${ }^{34}$ ), baimés ir kt. emocijų socialinị sujungimą galima laikyti iracionaliu, nebūtinai $\mathfrak{i}$ aplinkybes orientuotu fenomenu, jei jos tampa ịprastomis diskursyvinėmis interakcijomis. Užsienio politikos tyrimų kontekste ši pristatyta emocijos sampratos logika reiškiama dviem analizès lygmenimis: 1) užsienio politikos tapatybei svarbūs išorès (tarptautinès sistemos) veiksniai, kurie aktyvina emocijas (racionalus dirgiklis); 2) valstybès vidaus lygmeniu emocijos tampa manifestaciniu kodu, palaikančių tolesnị emocijos vyravimą (neracionalus diskursas). Taigi ne pati

\footnotetext{
${ }^{31}$ Tai veikia politikai, institucijos, medijos. Brentas Sasley analizuoja kaip emocijos konverguojasi tokiose plačiose bendruomenèse kaip valstybė. Brent S., "Affective Attachments and Foreign Policy: Israel and the 1993 Oslo Accords", European Journal of International Relations 16(4), 2010.

${ }^{32}$ Sautrette P., "You Dissin Me? Humiliation and post 9/11 Global Politics", Review of International Studies (2006), 32, 495-522.

${ }^{33}$ Heimann G., Löwenheim O., „Revenge in International Politics“, Security Studies, Volume 17, Issue 4, 2008.

${ }^{34}$ Sucharov M., „Imagining ourselves then and now: nostalgia and Canadian multiculturalism“, Journal of International Relations and Development (2013) 16, 539-565.
} 
emocinè reakcija, bet jos įdiskursinimas ar ịtapatybinimas, nereaguojant ị išorès dirgiklius ar aktualią aplinką, gali būti suvoktas kaip neracionalus procesas.

\subsection{Destrukciné baimès emocijos samprata}

Baimès emocija - viena svarbiausių žmogaus elgsenoje atpažistamų emocijų. Ją galima suvokti ịvairiai. Kai kuriais atvejais baimés prigimtis suvokiama kaip biologinè. Pavyzdžiui, teigiama, jog žmogus natūraliai bijo greitai artėjančių objektų. Tačiau laboratoriniai tyrimai rodo, jog baimè gali būti ir igyta $^{35}$. Baimès emocija gali būti ir socialinių struktūrų reiškinys, t. y. kolektyvinè emocija. Pavyzdžiui, baimé, kaip visuomeneje kylanti emocija, atsiranda dèl nesaugumo, dèl šiuolaikinio gyvenimo būdo (angl. insecurity with modern living), gyvenimo kokybès (angl. quality of life), netvarkos suvokimo (angl. perception of disorder) arba tiesiog reiškiasi kaip miestietiškas nerimas (angl. urban unease) $)^{36}$.

Priešingai nei neorealistai, baimę suvokę kaip objektyvią reakciją i struktūrinius pokyčius, Ulrichas Beckas socialinị-kultūrinị baimės fenomeną pateikia akcentuodamas, jog baimè kyla dèl konkrečios visuomenès subjektyvaus struktūros principo. Ją autorius įvardijo rizikos visuomene ${ }^{37}$. Beckas pažymi, jog laiko ir erdvès mobilumas naująsias rizikas (branduolinè, ekologinè, cheminè, genų inžinerijos) padare laiko ir erdvès neapibrežtas, todèl sunku jas visuomenei paaiškinti pagal kaltès ir priežastingumo ar atsakomybės principus. Kitaip tariant, Beckas kalba apie visuomenëje atsirandančias grèsmes ir baimes vien dèl visuomenès struktūros ir joje esančių kultūriniu filtrų, kurie veikia ir formuoja mūsų suvokimą, pobūdžio ${ }^{38}$. Apeliuodamas ị panašius argumentus Corey Robinas kalba apie politinę baimę, kylančią dèl visuomenejje atsirandančio kolektyvinio nerimo dèl savo gerovès, kurią sugriauti gali, pavyzdžiui, terorizmas, nusikalstamumas, visuomenès moralinių nuostatų irimas ${ }^{39}$.

\footnotetext{
${ }^{35}$ Igytos baimès pavyzdys gali būti J. B. Watsonas klasikinis sąlygojimo eksperimentas su dar metų neturinčiu berniuku. Pirmame etape berniukas nebijojo baltos žiurkès, balto triušio ir kitų baltų objektų. J. B. Watsonas kaskart pasirodžius baltai žiurkei šalia vaiko sukeldavo gąsdinantį triukšmą trenksmu. Po kiek laiko berniukas tik pamatęs baltą žiurkę krūptelèdavo imdavo verkti. Tokiu būdu mokslininkas pademonstravo, kaip atsiranda iki tol neegzistavusi baimè.

${ }^{36}$ Insecurities in European Cities. Crime-Related Fears Within the Context of New Anxieties and Community-Based Crime Prevention, <http:/cordis.europa.eu/documents/ documentlibrary/100124091EN6.pdf>, [žiūrèta 2015-09-02].

${ }^{37}$ Beck U., Risk Society. Towards a New Modernity, London: Sage Publications, 1992.

${ }^{38}$ Beck U., World at Risk, Cambridge: Polity Press, 2008.

${ }^{39}$ Corey R., Fear: The History of a Political Idea, Oxford: Oxford University Press, 2004.
} 
Barry Glassneris ${ }^{40}$ ir Holgeris Molderis ${ }^{41}$ tokị baimès įsitvirtinimą socialiniame gyvenime vadina baimès kultūra (angl. the Culture of Fear), kuri, anot autorių, turi didelę ittaką visuomenèje priimamiems sprendimams. Molderis pažymi, jog baimés kultūroje baimès emocija yra vyraujanti dèl nuolatinio neišvengiamos grèsmès, pasireiškiančios kaip valstybės (valstybès visuomenių, lyderių) nerimo, neužtikrintinumo, nestabilumo, pojūčio. Tai valstybes skatina ị ịvykius reaguoti sentimentaliai, emocionaliai, o ne pragmatiškai. Jei šis emocinis baimės krūvis issitvirtina tarptautinèje sistemoje - suvokiamų grèsmių laukas ir mastas gali labai išsiplèsti ir tapti tiesiog kultūriniu elementu. Kitaip tariant, baimè tampa ne tiek reakcija ị konkrečią (objektyvią) grèsmę, kiek pačios socialinès struktūros suvokimo aparato dalimi (baime tampa nepriklausoma nuo aplinkos). Tai iš dalies atitinka Davydo Campbello pristatytą pavojaus, kaip interpretacijos, o ne būtino ir neišvengiamo reagavimo ị konkrečią problemą, fenomeną ${ }^{42}$.

Tai ịvertinus svarbu atkreipti dèmesí, jog reikia atsargiai žiūrèti ị teiginị, kad baimés kultūra yra labai glaudžiai susijusi su anarchijos samprata, kuri pristatyta realistų darbuose. Straipsnio autorius manymu, teiginys, jog baimés vyravimas (arba tiesiog baimès kultūros vyravimas) yra būdingas anarchijai, ne tik netikslus, bet euristine prasme nepatogus. Sakydami, jog baimè yra anarchijos pasekmé, mes, viena vertus, per daug supaprastiname tai, kas yra ir kaip veikia anarchija, kita vertus, emocionalizuojame pačią anarchijos sąvoką. Šiame straipsnyje teigiama, jog anarchijoje baimés kultūra nebūtinai turi būti anarchijos pasekmè. Anarchija - tai struktūra, kurioje baimès kultūra susiklosto ir vyrauja kaip specifinè ịsitikinimu sistema dèl kitų nuo pačios anarchijos logikos nepriklausomų priežasčių. Iš dalies anarchijos sąvokos emocionalizaciją pastebejjo B. Buzanas, teigęs, jog valdžios nebuvimas anarchinèje sistemoje yra vertinamas neigiamai. Visai kaip skurdas ar ligos, kurie apibréžiami taip pat kaip trūkumas tam tikrų normalių savybių. Kitaip tariant, anarchija suprantama žodžio chaosas, netvarka prasme. Tokia asociacija pirmiausia suformuota $\mathfrak{i}$ tarptautinių santykių teoriją integravus Hobbeso anarchijos vaizdinị. Tai, anot Barry Buzano, klaidingas žodžio apibrèžimas, nes nepadeda suprasti

\footnotetext{
${ }^{40}$ Glassner B., The Culture of Fear: Why Americans are Afraid of the Wrong Things, New York: Basic Books,1999; Engin F. Isin, "The Neurotic Citizen," Citizenship Studies 8, no. 3, 2004; Konty M., Duell B., Joireman J., "Scared Selfish: A Culture of Fear's Values in the Age of Terrorism," The American Sociologist 35, no. 2, 2004; Rothe D., Muzzatti S., "Enemies Everywhere: Terrorism, Moral Panic, and U.S. Civil Society," Critical Criminology 12, no. 3, 2004.

${ }^{41}$ Molder H., „Culture of Fear and Status Conflict in Estonia - Russia Relationship“, Paper for ECPR Joint Sessions in Mainz, 2013.

${ }^{42}$ Campbell D., Writing Security: United States Foreign Policy and the Politics of Identity, Manchester: Manchester University Press, 1992.
} 
tai, kaip veikia tarptautinè sistema ${ }^{43}$.

Buzanas anarchiją siūlo suvokti tiesiog centrinès valdžios nebuvimo prasme, o pačią sąvoką vertinti kaip saugumo problemos formos, bet ne pačios problemos apibūdinimą. Kitaip tariant, saugumo siekio kontekste anarchijos eliminacija nèra nei būtina, nei tuo labiau pageidautina problemos sprendimo dalis. Anarchija yra tiesiog sistema, kuri nebūtinai turi būti konfliktiška ${ }^{44}$. Panašią anarchijos sąvoką pateikia Wendtas teigdamas, jog ,,anarchijos logikos“ per se nèra apskritai. Anarchija veikiau paaiškina tai, ko nèra (valdžios), o ne tai, kokia konkrečiai yra tarptautinè struktūra. Anarchija - tai tuščias modelis, kuriam prasmę suteikia žmonių, gyvenančių jos sąlygomis, nusiteikimai ir isivaizdavimai ${ }^{45}$.

Tokia logika veda prie išvados, jog anarchijos pobūdis gali būti labai ivvairių formų, kaip teigia Buzanas, - nuo idealios arenos atvirai kovai dèl galios (nebrandi anarchija) iki erdvès, palaikančios įvairovę ir dalyvių saugumą (brandi anarchija $)^{46}$. Wendtas anarchijos tipu (Hobbeso, Locke ir Kanto) klasifikaciją pateikia aiškindamas skirtingų idejjų pasiskirstymo ir jų internalizavimo atvejus. Esant Hobbeso anarchijos kultūrai, socialineje struktūroje vyraus kolektyvinis įsivaizdavimas, jog Kitas yra priešas, tad valstybės projektuodamos užsienio politiką orientuosis ị blogiausią variantą (blogiausio atvejo teorija), todèl valstybès priešiškus Kitus bus linkusios sunaikinti arba užkariauti. Locke kultūroje - vyraus rungtyniavimo kolektyvinis ịsivaizdavimas, paremtas suvereniteto instituto pripažinimu ir principu ,gyvenk ir leisk gyventi Kitam“. Kanto kultūra, anot A. Wendto, kyla iš ịsitikinimo, jog Kitu ketinimai taip pat yra taikūs. Visas šias autoriaus išskirtas anarchijos kultūras galima traktuoti kaip valstybių socialinių, psichologinių tarpusavio santykių tipus, galinčius formuoti savarankiškas logikas turinčias sistemas. Nors šiuo požiūriu visos pristatytos kultūros yra įsivaizdavimai ir psichologiniai tarpusavio santykiai - Hobbeso anarchijoje dèl subjektų saviizoliacijos ${ }^{47}$ ir anarchijos vaizdinio reiškimo uždaru valstybès lygmeniu, vyraus baimès prisodrinta ịsitikinimu sistema - „naikink arba būsi sunaikintas“. Kitaip tariant, Hobbeso anarchija dèl savo formos (anarchijos įsivaizdavimo konstravimas vyksta mažai ar išvis nesąveikaujant su aplinka) ir dèl turinio (subjektų santykiai paremti konfliktu ir vienas kito

\footnotetext{
${ }^{43}$ Buzan B., Žmonès, valstybès ir baimé: tarptautinio saugumo studijos po Šaltojo karo, Vilnius: Eugrimas, 1997, p. 196.

${ }^{44}$ Ten pat, p. 56.

${ }^{45}$ Wendt A., Tarptautines politikos socialinè teorija. Vilnius: Eugrimas. 2005, p. 328.

${ }^{46}$ Buzan B., Žmones, valstybès ir baime: tarptautinio saugumo studijos po Šaltojo karo, Vilnius: Eugrimas, 1997, p. 233.

${ }^{47}$ Subjektui save izoliavus nuo aplinkos (nuo tarptautinès sistemos Kitu) padideja tikimybè, jog aplinką jis reflektuos pagal subjektyvias, nuo išorinès informacijos atsietas, schemas.
} 
neigimu, o ne bendradarbiavimu) skiriasi nuo Locke ir Kanto anarchijų, todèl gali būti laikoma kaip visai kito tipo reiškinys.

Šių anarchijos kultūrų (ypač Hobbeso anarchijos skirtumo nuo Locke ir Kanto anarchiju) susiklosčiusius skirtumus būtų galima paaiškinti kaip anarchijos kultūrai būdingo struktūros subjektų tapatybinio atvirumo lygio priežastị. Teoriškai galima visus tapatumus ịsivaizduoti atvirumo ir uždarumo tiesẻje. Kuo tapatybe uždaresnè, tuo jos tapatybinis kodas mažiau priklausomas nuo kitų tapatumų ir tuo mažiau toks tapatumas yra paveikus išorès procesams. Ribiniu (maksimaliu) tapatybinio uždarumo atveju turètų būti iš esmès neigiama bet kokia kitokios tapatybès (taigi ir pačios tapatybès kaip tokios) egzistavimo galimybè. O kuo tapatybè atviresnè, tuo ji paveikesnè išorès pokyčiams ir tuo jos tapatybinis kodas labiau priklausomas nuo kitų tapatumų. Ribiniu (maksimaliu) tapatybinio atvirumo atveju tapatumas taip pat išnyksta (nes nebèra skirtumo tarp Aš ir Kitas), tačiau pats tapatybès nykimo procesas, priešingai nei tai vyktų per tapatybinį uždarumą, yra pozityvus Kitus ịtraukiant, o ne negatyvus Kitus neigiant ar naikinant. Taigi, suvokiant, jog kiekviena tapatybè turi skirtingą polinkị i uždarumą ar atvirumą (ir realiai niekada nesusiklosto minètų ribinių atvejų pagrindu), prasminga tapatumą skirstyti $\mathfrak{i}$ ekstravertišką ir intravertišką tapatumą.

Šią elementarią seką svarstant hipotetiniu lygmeniu nesunkiai prieisime prie išvados, jog idealus uždaro tapatumo tipas bus kur kas stabilesnis nei idealus atviro tapatumo tipas. Idealiu, visiškai intravertiškos tapatybès atveju tapatybė bus pastovi, atspari tapatybiniams šokams ${ }^{48}$, kurie gali suardyti socialinius tapatybinius junginius. Tačiau toks stabilumas įmanomas tik ribiniu tapatybės uždarumo (kai kitos tapatybės jau nebeegzistuoja) atveju. Tapatybinis uždarumas struktūroje, kurioje egzistuoja kiti tapatybiniai subjektai, visada jaus didesnę trintị ir išorinị spaudimą nei ekstravertiško tipo tapatumai, galintys tiek greičiau prisitaikyti prie kintančiu sąlygų, tiek galimas tapatybines trintis neutralizuoti per tapatybių integraciją. Galima teigti, jog būtent tai yra viena esminių priežasčių, kodèl Hobbeso anarchija, paremta tapatybiniu intravertiškumu, yra konfliktiška (todèl nestabili), o Locke ir Kanto anarchija, nors ir skirtingais lygiais, tačiau paremtos tapatybiniu ekstravertǐ̌kumu, yra taikios ir struktūriniu atžvilgiu stabilios struktūros (žiūrèti 1 pav.). Taip pat galima teigti, jog tapatybès vieta atvirtumo ir uždarumo tieseje tiesiogiai siesis su tuo, kokią ir kaip tapatybinis subjektas jaus baimę. Pavyzdžiui, Locke ir Kanto

\footnotetext{
${ }^{48}$ Tapatybinį šoką galima suvokti kaip procesą, kurio metu per trumpą laikotarpị vienos tapatybinès konstrukcijos atmetamos ir keičiamos kitomis. Pavyzdžiui, Baltijos valstybėms atkūrus nepriklausomybę prasidèjo sparti šalių tapatybių orientacija ị iki tol svetimą, individualistinèmis ir Vakarų demokratinèmis vertybemis paremtą sistemą.
} 
anarchijose baimè dèl tapatybinio ekstravertiškumo turètų būti tiesiogiai priklausoma nuo išorès veiksnių. O Hobbeso anarchijoje baimè kils ir bus palaikoma išimtinai vidinių veiksnių, todèl savo forma ir turiniu kokybiškai skirsis nuo ankstesnių dviejų tipų (kokybiniai baimès skirtumai intravertiškų ir ekstravertiškų tapatumų pavyzdžiuose aptariami antrojoje dalyje). Taigi jei baimė gali būti racionali (kaip reakcija ị objektyvią tikrovę) ekstravertiškose Locke ir Kanto anarchijų tipuose, intravertiškoje Hobbeso anarchijoje ji veikiau gimsta ir formuojasi kaip emocija subjekto viduje, todèl turètų būti traktuojama kaip iracionalus fenomenas. Tai iš esmès yra vienas svarbiausių baimès emociją bei tapatybę siejančių veiksnių.

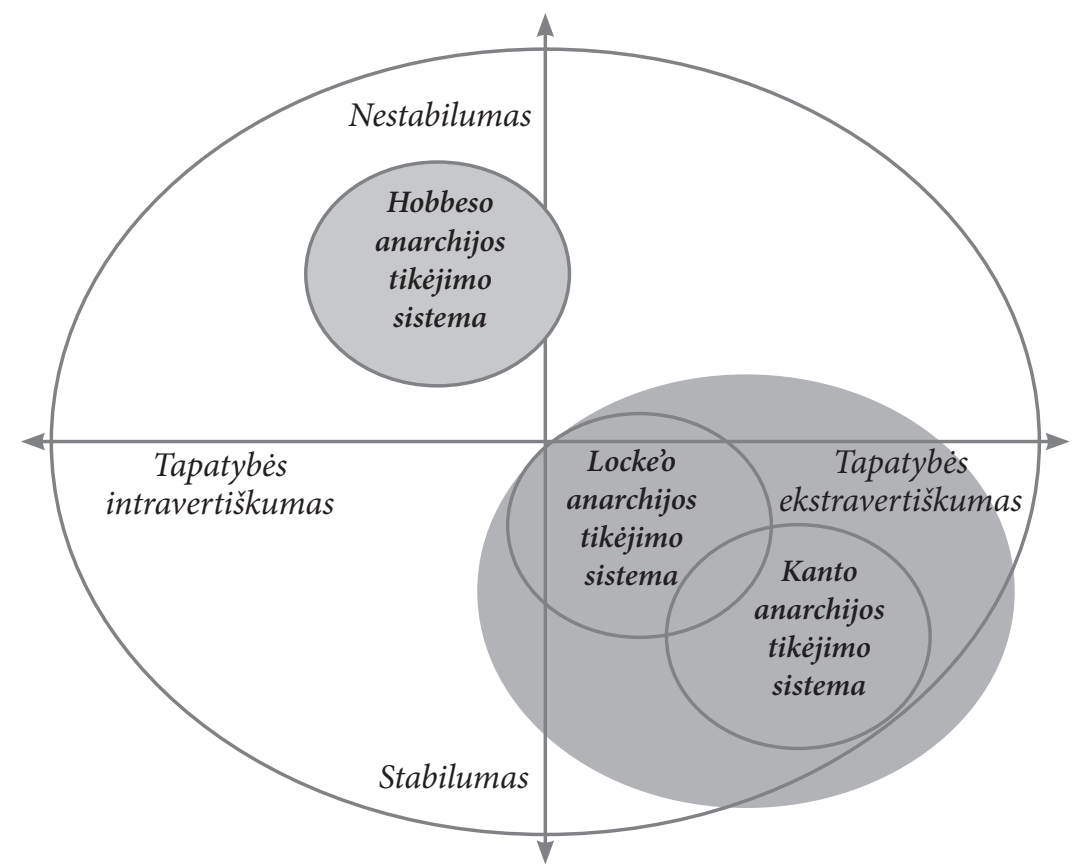

1 pav. Anarchijos kultūrinių tipų konstravimo žemėlapis

Tai pastebi Lebowas, savo tarptautinių santykių teorijoje baimę charakterizavęs kaip emociją (iracionalų veiksnį, bet ne kaip fundamentalią žmonių paskatą), trikdančią tarptautinių sistemų nusistovèjusias kultūros (pavyzdžiui, garbès, troškimo, proto) principų struktūras. Taigi baimès kultūros įsitvirtinimas socialinèse struktūrose gali suardyti nusistovejusias (Wendto terminais kalbant, internalizuotas) kultūrines praktikas. Kitaip tariant, jei anarchija gali turèti rungtyniavimo ar draugiškumo kultūros struktūrą, tai baime paremtos anarchijos kultūros tipo nèra, nes baimès vyravimas anarchineje sistemoje yra 
veikiau sutrikdytos, suardytos sistemos pavyzdys, kai intravertiški tapatumai kuria savarankiškas, tarpusavyje nederančias tarptautinès struktūros suvokimo variacijas. Dèl to tarptautinès struktūros (kaip aiškaus subjektų sąveikos mechanizmo) iš esmès nèra.

Lebowas aiškina, jog baimès visuomenèje (pavyzdžiui, priešingai nei garbès visuomeneje) nei tikslai, nei priemonès nèra paremti kokiomis nors normomis. Kita vertus, pati baimé gali būti vyravusių sistemų ir hierarchijų kaitos priežastis (sistemos kliuvinys). Pavyzdžiui, skirtingų tipų anarchijos kultūrose baimè gali reikštis skirtingai: garbès visuomenèse sistemos irimą gali paskatinti statuso netekimo baimé, troškimo visuomenèse grèsmingas transformacijas sukelti gali atsiradusi baimé, paremta klasine ittampa ${ }^{49}$. Taigi dèl savo destrukcinio pobūdžio baimé skiriasi nuo kitų idealių tipų, kuriuos kaip anarchijos prototipus pristate Lebowas (garbès, troškimų ir proto kultūra) ir Wendtas (Lockeo ir Kanto anarchija).

Tokios tvarką ardančios emocijos, neparemtos kokiomis nors pozityviomis normomis ${ }^{50}$, vyravimas diskursuose gali reikšmingai paveikti tarptautinès sistemos subjektų konfliktų priežastis, formas ir baigtis. Vienas svarbiausių šiuolaikinès konflikto teorijos kūrejjų Lewis Alfredas Coseris išskyrè nerealaus konflikto ${ }^{51}$ sąvoką, kuri, anot autoriaus, nurodo, jog kai kuriais atvejais konfliktai kyla iš agresyvių individo impulsų, todèl konflikte svarbūs tampa ne realūs interesai, bet pati emocinè raiška. Kitaip tariant, individo konfliktiškas elgesys yra nukreiptas ne į konkretaus rezultato siekị, bet pačią agresyvią veiklą, tampančią individų emocine iškrova ${ }^{52}$. Tad kuo stipresnès konfliktuojančių pusių emocijos - tuo stipresnis konfliktas ir sunkiau nustatomos ir išsprendžiamos realios konflikto priežastys. Ši Coserio patvirtinta hipotezè tarsi patvirtintų baimès kultūros, kurios dominantè yra baimès emocija, destrukcinị pobūdị ir tai, jog baimès emocijos vyravimo atveju pati kultūra (o ne objektyvus, savarankiškas baimès šatinis) tampa visuomenès (ir politikų) baimių priežastimi. Esant tokioms aplinkybėms konflikto pusių suartejimas yra sunkiai tikètinas ar net neįmanomas.

Žvelgiant iš konstruktyvistinès perspektyvos, baimè (kaip emocija) taip pat gali būti traktuojama kaip tarptautinès sistemos kliuvinys (makro

\footnotetext{
${ }^{49}$ Lebow N. R., A Cultural Theory of International Relations, Cambridge: Cambridge University Press, 2008, p. 27.

${ }^{50}$ Pozityviomis normomis, pavyzdžiui, paremtos ekstravertiškos, aplinkos procesus atliepiančios ir Save tarp Kitu matančios tapatybès.

${ }^{51}$ Realus konfliktas suprantamas kaip priemonė, padedanti siekti užsibrěžtų rezultatu. Svarbiausias konflikto siekis yra konflikto pusių suartèjimas.

${ }^{52}$ Coser Lewis A., Social Conflict and the Theory of Social Change: Violance and Social Strukture, Science and Psychoanalysis, ed. Mascerman J., Vol.7, New York, 1963, p. 34.
} 
lygiu), nors ir turintis stabilumo ir tvarumo palaikymo funkciją mikro (valstybès vidaus) lygiu. Pavyzdžiui, baimé gali vienyti tautą (ypač eskaluojant ją viešajame diskurse) nacionalinès grèsmès akivaizdoje. Tai susiję su tuo, jog pats bendruomenès formavimas gali būti suvokiamas kaip sociopsichologinių paskatu stumiamas aktas, kuriame vyraus baimé, jog grupei nepriklausantys Kiti gali ar ketina pakenkti grupès nariams ${ }^{53}$. Šiuo būdu baimè gali būti paskata aiškiau, tvirčiau ir greičiau apibrežti kolektyvinị tapatumą. Tačiau kartu toks baimès dominavimas identiteto naratyve programuoja nestabilumą ir iracionalią subjektų sąveiką tarptautiniu lygmeniu, kuriame intravertiškumu ir baime paremti tapatumai sąlygos baime paremtos sistemos atsiradimą. $\mathrm{Ne}$ atsitiktinai Lebowas pastebi, jog politineje ir psichologineje literatūroje Kito suvokimas yra labiau ideologinis (šiame darbe ideologinis atitiktų teiginị, jog toks pavaizdavimas formuojamas subjektyviai valstybès viduje) nei realus pavaizdavimas ${ }^{54}$. Nors baimès paskata gali skatinti bendradarbiavimą, tačiau šis bendradarbiavimas, tikètina, truks tik tiek, kiek ir pati grèsmè, dèl kurios kooperuojamasi. Todèl baime paremtą kultūrą Lebowas pristato kaip spąstus, $\mathfrak{i}$ kuriuos lengva patekti, bet sunku iš jų ištrūkti ${ }^{55}$.

Taigi baimès emocijos vyravimas (baimès kultūros realizacija) tarptautinių santykių kultūroje didina tarptautinès sistemos nestabilumą, jos sudètinių dalių (valstybių) konfliktiškumą, nepasitikèjimą, nerimą, skirties tarp Aš ir Kitas didejjimą. Kitaip tariant, baimès kultūroje, kai emociniai motyvai trikdo racionalaus situacijos vertinimo ir sprendimo galimybes, išauga tarptautinès sistemos poliarizacijos ir destabilizacijos tikimybe ${ }^{56}$. Šia prasme baimès kultūra koreliuoja su moralines panikos ${ }^{57}$, identiteto dilemos ${ }^{58}$ ir saugumo dilemos ${ }^{59}$ konceptais, nurodančiais situacijas, kada racionalus sprendimas dèl susidariusios situacijos yra sunkiai pasiekiamas.

\footnotetext{
${ }^{53}$ Rousseau D. L., Garcia-Retameo R., „Identity, Power, and Threat Perception. A CrossNational Experimental Survey“, Journal of Conflict Resolution, 4 (51), 2007, p. 744-771.

${ }^{54}$ Lebow N. R., A Cultural Theory of International Relations, Cambridge: Cambridge University Press, 2008, p. 488.

55 Ten pat, p. 92.

${ }^{56}$ Molderis tokios kultūros vyravimo pavyzdžiu laiko situaciją po Pirmojo pasaulinio karo, kada baimès kultūrą propagavusios ir baimės kultūrą tarptautinèje sistemoje įtvirtinusios revizionistinès Sovietų Sąjungos, nacistinès Vokietijos ir fašistinès Italijos galios pasaulị ịvèle ị Antrąji pasaulinị karą. Molder H., "Culture of Fear and Status Conflict in Estonia - Russia Relationship“, Paper for ECPR Joint Sessions in Mainz, 2013.

${ }^{57}$ Cohen S., Folk Devils and Moral Panics: the Creation of the Mods and Rockers. London: Routledge, 2002.

${ }^{58}$ Molder H., „Culture of Fear and Status Conflict in Estonia - Russia Relationship“, Paper for ECPR Joint Sessions in Mainz, 2013, p. 17.

${ }^{59}$ Baimès kultūrai būdinga klasikinè saugumo dilema - vieno saugumas reiškia kito nesaugumą. Saugumo dilemą gali sukelti ar paskatinti šie veiksniai: 1) santykių saugumo aplinkoje stoka, 2) išaugęs tarpusavio nepasitikejimas, 3) neveikiančios arba blogai veikiančios dialogo institucijos.
} 
Apibendrinant baimès emocija darbe suvokiama ne vien kaip bijojimas ar (realistine prasme) kaip natūrali anarchijos išvestinè, bet kaip kultūrinis kliuvinys atlikti racionalius veiksmus. Baimès emocija dèl savo intravertiško pobūdžio nèra logiška reakcija ị tarptautinę sistemą, todèl baimès emocija veikiau yra jèga, kuri griauna tarptautinę sistemą, o įsivyrauti gali tada, kai sistema yra nestabili ar, pavyzdžiui, besikeičianti. Taigi baimès apibrèžties kildinimas vien tik iš anarchijos, kaip chaoso, yra neproduktyvus euristine prasme, nes pati baimé gali veikti kaip struktūras destabilizuojantis veiksnys kooperatyvinių sistemų kultūriniuose diskursuose, ir nebūti vyraujanti ar esminè stabiliose, tačiau neintegruotose sistemose. Kitaip tariant, šioje sampratoje, anarchija nèra grèsmès, taigi ir baimès, priežastis, baimè - tai kliuvinys anarchinei tarptautinei sistemai veikti brandžiai (Buzanas) ar pagal kokią nors aiškią logiką (Wendtas, Lebowas).

\section{Grèsmès, kaip baimès priežasties, suvokimo sampratos}

Apibrèžus baimès emocijos sąvoką ir baimés kultūros (baimès emocijos vyravimą) poveikị socialinèms struktūroms toliau reikia charakterizuoti baimès kilimo priežastis. Atsižvelgiant ị pateiktą samprotavimą, logiška baimę traktuoti kaip reakciją $\mathfrak{i}$ kilusios grèsmės suvokimą. Toliau darbe, integravus realistų, liberalų, konstruktyvistų ir pirmojo analizès lygmens nuostatas, paremtas užsienio politikos tyrimų koncepcijomis, pristatomos kilusios grèsmès suvokimo teorinès sampratos: grèsmè kaip galios asimetrijos pasekmé, grèsmé kaip identiteto asimetrijos pasekmé ir grèsmè kaip isitikinimu sistemos lemta pasekmè. Būtina pažymèti, jog pateikiamos grèsmės suvokimo sampratos darbe traktuojamos kaip skirtingos, viena kita keičiančios ir tarpusavyje susipynusios grèsmès priežasčių ịsivaizdavimo suvokimo schemos (idealūs tipai). Taigi nè vienas iš pristatomų modelių nèra traktuojamas kaip generalinė grèsmès suvokimo teorija. Veikiau visų šių sampratų pasitelkimas sudaro galimybes kompleksiškai analizuoti baimès veiksnio ịtaką užsienio politikos formavimui ir igyvendinimui. Svarbu pabrèžti, kad pateiktos baimès suvokimo sampratos yra pristatomos kaip socialiniai ịsivaizdavimai, tarpusavyje besiskiriantys tapatybės ekstravertiškumo ir intravertiškumo lygiu ar skirtingu grèsminamo socialinio fenomeno (galios, identiteto) pasirinkimu. Visa tai neleidžia pristatytų tipų (galios ir identitetų asimetrijų ir ịsitikinimų sistemos) traktuoti kaip tiesiog truputị švelnesnių liberalų, realistų ar konstruktyvistų, realybę gebančių suspausti ị vieną pažintinę schemą, teiginių. 


\subsection{Galios asimetrija}

Grèsmès suvokimas, paremtas galios asimetrija, iš dalies sutampa su tarptautinių santykių realistų požiūriu į grèsmès ir baimès priežastis. Šioje tarptautinès politikos aiškinimo perspektyvoje svarbiausias grèsmès ir baimės šaltinis yra galios asimetrijos anarchinejje tarptautinių santykių sistemoje susiklostymas ir didejjimas. Pavyzdžiui, jau Thucydide dare išvadą, jog Atennu ir Spartos karo priežastis buvo galios asimetrija tarp dviejų polių ir tos asimetrijos didejjimas. Kitaip tariant, bet koks kito tarptautinès sistemos subjekto galios igijimas yra potencialiai grèsmingas ir pavojingas. Tai, anot realistų, diskusijų nekelianti tezè. Anot realistinio požiūrio ị politiką pionierių Machiavellio ir Hobbeso, žmogus ar valstybė visada turi turèti nuolatinị siekị igyti ir plètoti galią. Tai anarchijos programuojamas rezultatas.

Šiuos teiginius Waltzas integravo ị savo mokslinę tarptautinių santykių teoriją. Waltzas teigia, jog grèsmé yra galios asimetrijos funkcija. Jei, pavyzdžiui, valstybe $\mathrm{X}$ turi daugiau galios nei valstybè $\mathrm{Y}$, tai $\mathrm{X}$ baimé yra pagrịsta, nes niekas anarchineje sistemoje $\mathrm{Y}$ negali sulaikyti nuo jègos panaudojimo prieš $\mathrm{X}$. Taigi atpažinti ir suvokti grèsmę remiantis Waltzo neorealistine tradicija nèra labai sudètinga: jei nesunkiai ̨̨manoma išmatuoti galios asimetriją tarp sistemos subjektų, tai suprasti, ar grèsmė yra ar ne, bus taip pat paprasta ${ }^{60}$. Trumpai tariant, pakanka ịvertinti ir palyginti karinius, ekonominius, politinius, geografinius, demografinius kriterijus. Pavyzdžiui, kaimyninè valstybė X, palyginti su valstybe $\mathrm{Y}$, disponuoja didesniais kariniais, ekonominiais, demografiniais resursais ir turi didelę arba didejjančią politinę ịtaką. Tokia situacija natūraliai valstybę Y verčia galios asimetriją vertinti kaip grèsmingą. Jei valstybė Y tai ignoruos, tai, kaip jau minèta, rizikuos būti nubausta sisteminès logikos (nukariauta, aneksuota ir pan.). Todèl nepaisant to, ar valstybė yra demokratiška, ar autokratiška, katalikiška ar musulmoniška, kapitalistinè ar komunistinė, kiekviena valstybė galios asimetrijos situacijai susiklosčius jaus grèsmę ir sieks atsispirti didesnę galią turinčiai ar tiesiog galią iggyjančiai valstybei. Taigi baimé, kuri kils kaip reakcija ị grèsmę, kilusią dèl galios asimetrijos, bus nulemta iš esmès materialių faktorių (didesnès karinès galios, stipresnès ar sparčiau augančios ekonomikos ir pan.). Tai reikštu, jog baimė yra racionali reakcija. Jei tarptautinès sistemos logika tokia, kaip ją pristato Waltzas, tai bijoti (stipresnio ar stiprejjančio kito subjekto) reiškia elgtis racionaliai, atsargiai, adekvačiai esamomis sąlygomis.

Tačiau realistinėje tarptautinių santykių perspektyvoje ne visiškai suta-

\footnotetext{
${ }^{60}$ Waltz K., Theory of International Politics, New York: Random House, 1979.
} 
riama, kodèl kyla grėsmè. Stephenas Waltas - vienas iš teoretikų, reflektavusių Waltzo grèsmès vertinimo logiką. Pagal Waltą grèsmè - tai 1) karinès galios, 2) geografinio artumo, 3) ofenzyvinio pajėgumo ir 4) agresyvių intencijų funkci$\mathrm{ja}^{61}$. Tai svarbus indèlis aiškinant grèsmès genezę, nes parodo, jog valstybès veikiau balansuoja prieš grèsmę, o ne prieš galią. Pavyzdžiui, Kanada po Antrojo pasaulinio karo nebalansavo prieš savo didžiąją kaimynę JAV, nes nemanė, jog amerikiečiai prieš juos turi agresyvių intencijų (t. y. JAV ir Kanados santykiuose nebuvo ketvirtojo grèsmès veiksnio). Šie veiksniai, nors ir išlaiko grèsmès supratimą, kaip galios asimetrijos atpažinimo principą, šiek tiek atpalaiduoja nuo griežto struktūrinio mąstymo ir verčia gilintis ị valstybès, biurokratijos ir individo analizès lygmenis. Taigi Walto teiginiai leidžia suabejoti Waltzo argumentu, jog visos valstybès iš esmès vienodos, todèl grésmès ir baimés priežastys išvien materialios. Pavyzdžiui, agresyvios intencijos gali būti susijusios su religija, režimo tipu, valstybès sprendimų prièmimo struktūra, statusu ekonominejje sistemoje.

Reikia pabrèžti, jog grèsmès suvokimas per galios asimetriją nebūtinai turi būti suprantamas kaip realistų logikos pripažinimas ar jos atkartojimas. Realistų teiginiai baimès kaip galios asimetrijos sampratai veikiau svarbūs kaip baimès objekto (galios asimetrijos), bet ne kaip baimès ontologijos (valstybiu agresyvumas ir savanaudiškumas igimtas) orientyrai ${ }^{2}$. Taigi jei galios asimetrijos veiksnys nebus suvokiamas kaip tarptautinès struktūros perpetuum mobile, tai galios vertinimas, priklausomai nuo situacijos, bus tiesiog natūrali ir net racionali reakcija $\mathfrak{i}$ aplinką. Tačiau jei galios asimetrijos principas nepriklausomai nuo aplinkos ir jos pokyčių dominuoja ar net tampa identiteto dalimi - galima kalbèti apie galios asimetrijos metodą kaip ịsitikinimu sistema. Kitaip tariant, galios asimetrijos samprata nurodo, jog grèsmè ir baimè yra dinamiška dèl orientacijos ị baimès objekto elgseną (galios ir jos panaudojimo

\footnotetext{
${ }^{61}$ Walt S., The Origins of Alliances, Ithaca, New York: Cornell University Press, 1987.

${ }^{62}$ Toks baimès objekto ir baimès prigimties atskyrimas yra gana problematiškas, nes realistinèje teorijoje abu šie baimės suvokimo aspektai yra glaudžiai susiję. Anot realistų, baimès asimetrija nieko nereikštų, jei valstybès tikètų taikia kitų valstybių prigimtimi. Tačiau toks baimès ontologijos ir baimès objekto supynimas yra pavojingas, nes tokiu atveju visos galingos valstybès turi būti traktuojamos kaip pavojingos, baimę keliančios valstybess (pavyzdžiui, Morgenthau, Waltzo naratyvai). Galima manyti, jog Walto sampratoje baimès prigimties ir baimės objekto sąryšio intensyvumas yra kur kas laisvesnis, todèl tik dalis galingų valstybių (atitinkančių geografijos, galios ir agresijos realizacijos parametrus) yra traktuojamos pavojingomis ir baimę keliančiomis. Darbe pristatomame galios asimetrijos modelyje anarchijos, grèsmès ir baimès ontologija nẻra pozityvistinè. Agresyvumas nèra suvokiamas kaip valstybès prigimties bruožas, o anarchija yra tiesiog socialinè konstrukcija. Todèl didesnę ar didejjančią galią igyjantis subjektas dèl galimybès panaudoti galią, bet ne dèl to, jog jis iš prigimties instinktyviai norètų tą galią panaudoti (arba dèl to, jog anarchija kažkaip verstų tą galią panaudoti), bus traktuojamas kaip grèsmę keliantis subjektu. Tad galios asimetrijos modelis suponuotu, jog ne visos valstybès yra vienodos - potencialios agresorés. Kitaip tariant baimè tai veikiau dinamiškas procesas, bet ne tapatybèje ịsitvirtinęs pasyvus elementas.
} 
generavimą ir iš dalies Walto aprašytą grèsmės balansavimą), o ne ị jo prigimtị. Tai susiję ir su tuo, jog galios asimetrijos modelyje analizuojamas subjektas turès ị ekstravertiškumą linkusị tapatumą, kai realistų (ypač klasikinių ir iš dalies Waltz) pristatomos valstybės šiame kontekste dažniau labiau atitiktų intravertiško tapatybinio tipo veikejus. Taigi galios asimetrijos logika suvokiama grèsmé gali net prieštarauti kai kuriems realistams, kurie kitas valstybes matydami kaip priešus iš prigimties, labiau atitiktų šiame darbe pristatomos įsitikinimu sistemos, o ne galiu asimetrijos struktūrinius aspektus.

\subsection{Identiteto asimetrija}

Grésmės suvokimas per identitetų asimetriją paremtas liberalų ir konstruktyvistų socialinès realybės ịsivaizdavimu. Jei galios asimetrijos sampratoje socialinis pasaulis iš dalies yra stabilus (aktyvus ir dinamiškas galios persiskirstymas - grèsmės šaltinis), turintis maždaug aiškius dėsningumus (suvereniteto išsaugojimo, santykinès galios ir santykinio saugumo principai), tai identitetu asimetrijos samprata nurodo ị kur kas aktyvesnę, tapatybès kaitos dinamika pagrịstą socialinę ir vertybių erdvę. Tai atitinkamai keičia ir tai, kaip suvokiama grèsmès ir baimès prigimtis.

Liberalų grèsmès suvokimas susijęs su, pasikėsinimu ị egzistuojančios, vakarietiškomis vertybėmis (laisva rinka, demokratija, žmogaus teisès) paremtą tvarką. Kitaip tariant, pagal šią sampratą grèsmè kyla dèl bandymo kvestionuoti homo economicus primatą. Liberalai yra ịsitikinę, kad būtent šios vertybès yra valstybès galios, klestẻjimo ir saugumo šaltinis. Kitaip tariant, visi turi galimybę ir teisę ì galią, klestèjimą, saugumą ir išsivystymą. O ignoravimas universalių liberalių vertybių yra siejamas su prieštaravimu modernizacijai ir valstybès klestejimui. Tai puikiai iliustruoja dualistinè vystymosi teorija, kuri akcentuoja, jog neišsivysčiusių valstybių skurdas ir politinis nestabilumas kyla dẻl pačių valstybių nesugebejimo priimti ir igyvendinti liberalaus valstybès organizavimo mechanizmo ${ }^{63}$. Šis valstybių nenoras ar nesugebejimas liberalizuotis, demokratizuotis liberalioje teorijoje gali būti suvokiamas kaip grèsmès šaltinis. Tai puikiai iliustruoja Davidas Rousseau teigdamas, jog revizionistinès galios (galios, kurios ne tik nesutinka integruotis, bet ir turi potencijos oponuoti status quo sistemai ir jos vertybėms) kyla dèl kelių priežasčių: 1) individų ar valstybės vadovų neišsprusimo (tai didina galimybę, jog atsiras lyderių su nedorais siekiais); 2) nede-

\footnotetext{
${ }^{63}$ Išsamus dualistinès teorijos pavyzdys pateiktas Johno Hickso darbe The Remaking of a Unipolar World The Remaking of a Unipolar World. Hicks J., A Theory of Economic History, Oxford: Oxsford University Press, 1969.
} 
mokratinės valstybės valdymo struktūros ir laisvosios rinkos taisyklių nepaisymo (tai, anot liberalų, skatina atsirasti renegatiškoms valstybèms); 3) liberalių ir daugiašalių ekonominių ryšių ir tarptautinių institucijų stokos ${ }^{64}$. Šios sąlygos gali tiek skatinti revizionistinių galių (potencialių grèsmių) atsiradimą, tiek pačios būti suvokiamos kaip grèsmė, nes jų vyravimas grasina sugriauti tvarką, kurioje karines grèsmes ir karinị galinèjimąsi pakeitè kur kas saugesnės ir, svarbiausia, pažangą laiduojančios ekonominès varžybos.

Taigi liberalams suvokiant grèsmes svarbiausias veiksnys yra identitetas. Jei, pavyzdžiui, demokratinès, liberalios rinkos valstybė ginkluojasi (ar kitaip keičia galios pasiskirstymą), tai ji nebūtinai bus traktuojama kaip grèsmè tokios pat demokratinès valstybès. Kitaip tariant, revizionistinès valstybės atpažinimui yra svarbus pats jos neatpažistamumas. Jei nesugebame jos priskirti kategorijai Mes, tai didelè tikimybè, jog bet kokios valstybès politinès, ekonominès ir karinès ambicijos bus traktuojamos kaip grèsmè $\dot{e}^{65}$. Kita vertus, liberalai grèsme gali laikyti ir aplinkybes, kurios palankios gimti revizionistinei galiai. Pavyzdžiui, grésminami gali būti nedemokratiniai režimai, kurie siekia ar ateityje gali siekti igyti daugiau galios.

Galiausiai liberalai turi aiškią tokių grèsmių neutralizavimo strategiją. Panaceja grèsmèms spręsti yra pasaulio demokratizacija ir liberalizacija, kitaip tariant, pasaulio tapatybių universalizacija ir homogenizacija (taigi šiam požiūriui būdingas tapatybinis ekstravertiškumas). Tai iliustruoja Michaelis J. Boyle as savo straipsnyje teigdamas, kad JAV po $2001 \mathrm{~m}$. rugsèjo $11 \mathrm{~d}$. atakų terorizmo grèsmès sprendimą tiesiogiai susiejo su Irako ir Afganistano demokratizacija ${ }^{66}$. Taigi esamos ar besiformuojančios revizionistinès galios (grèsmingi Kiti) gali būti pozityviai neutralizuojamos - ịtraukiant per Kito liberalizaciją, demokratizaciją. Kuo tapatybinis $A \check{s}$ bus ekstravertiškesnis, tuo ši grèsmių neutralizacija per ịtraukimą bus intensyvesnè. Šis reikšmingas aspektas nurodo, jog šiame grèsmès sampratos modelyje nèra fiksuoto, egzistencinio grèsmès šaltinio (žiūrèti 2 pav.). Grèsmè ir jos lygis yra dinamiškas reiškinys, tiesiogiai priklausomas nuo tarptautinių ir tarpvalstybinių santykių pobūdžio. Šią tezę iš esmès pagrindžia Davidas L. Rousseau, gindamas teigini,

\footnotetext{
${ }^{64}$ Rousseau D., Identifying Threats and Threatining Identities: The Social Construction of Realism and Liberalism, Stanford University Press, 2006, p. 32.

${ }^{65}$ Daugeliu atvejų čia svarbu ir galios asimetrija, t. y. grèsmé turi ne tik nepriklausyti Mes kategorijai (vertybių atpažinimas), bet ir turi turèti pakankamai galios būti atpažinta kaip revizionistinè galia (materialus nustatymas).

${ }^{66}$ Boyle M., „Between freedom and fear: Explaining the consensus on terrorism and democracy in US foreign policy“, International Politics Vol. 48, 2/3, 2011, p. 412-433.
} 
jog tapatinimasis su Kitu yra negatyviai proporcingas grèsmės suvokimui ${ }^{67}$. Kitaip tariant, identitetas yra tarsi indikatorius grèsmès suvokimui.

\subsection{Isitikinimy sistema}

Pristatytuose grèsmès sampratos modeliuose grèsmès suvokimas ir grèsmès suvokimo intensyvumas yra susijęs su reikšmingų kintamųjų (galios, identiteto) dinamika. Taigi šiuos modelius galima vertinti kaip ị tarptautinę aplinką ir i joje vykstančius procesus reaguojančius modelius. Kitaip tariant, grèsmè nors ir turi aiškiai apibrèžtas priežastis, tačiau neturi fiksuoto šaltinio ${ }^{68}$.

Grèsmè, nuolatinis grèsmès jautimas gali būti tiesiog užprogramuotas socialinių darinių mąstymo ir ịsitikinimų sistemose (pavyzdžiui, Becko rizikos visuomenè). Puikus tokios grèsmés sampratos pavyzdys yra pateikiamas Alastairo Johnstono darbe, kuriame autorius analizuoja atsiminimų vaidmenị (kaip šalies lyderiai atsimena vienus ar kitus ịvykius) užsienio politikoje. Johnstonas ne tik teigia, jog šalių visuomenès ir šalies lyderių preferencijos gali formuoti valstybės užsienio politiką, bet ir parodo, jog grèsmès yra veikiau vidaus, bet ne struktūros (kaip aiškintų Wendtas) reiškinys ${ }^{69}$. Savo darbe Johnstonas išanalizavęs Kinijos karinius tekstus atpažino aktyvią, paralelinę ịsitikinimu sistemą, kuri, ̣̇sitvirtinusi užsienio politikos diskursuose, veikia jos formavimą ir ịgyvendinimą. Ją autorius ịvardijo kaip para bellum - ịsitikinimą, jog būtina ruoštis karui.

Autoriaus nuomone Para bellum ịsitikinimu sistema yra paremta ịsitikinimais ir stereotipais, bet ne tarptautinès aplinkos stebėjimu (galios ar identitetų asimetrijų atpažinimu), jog karas yra pastovus žmogaus bendravimo elementas, kad kariniai pajègumai yra svarbūs sprendžiant tarptautines problemas, bei tikejimu, jog konfliktas visada yra nulinès sumos žaidimas (tavo išlošis yra mano pralošimas) ${ }^{70}$. Toks grèsmès suvokimas iš esmès skiriasi tiek nuo galios, tiek nuo identitety asimetrijos modelių tuo, jog grèsmè nepriklauso (arba mažai priklauso) nuo aplinkos ir jos pokyčių. Kitaip tariant priešingai nei anksčiau minèti baimès įsivaizdavimo modeliai ịsiti-

\footnotetext{
${ }^{67}$ Rousseau D., Identifying Threats and Threatining Identities: The Social Construction of Realism and Liberalism, Stanford University Press, 2006.

${ }^{68}$ Pavyzdžiui, liberalų sampratoje grèsminama nedemokratinè, revizionistinè erdvė ar atitinkamos šios erdvès vertybės turi potencialą trauktis. Galios asimetrijos atžvilgiu - nėra vienos grèsmės šaltinio nes atstačius galios pusiausvyrą buvęs revizionistas gali tapti reikšminga šios pusiausvyros dalimi.

${ }^{69}$ Jounston Alastair I., Cultural Realism, Strategic Culture and Grand Strategy in Chinese History, Princeton: Princeton University Press, 1995.

${ }^{70}$ Ten pat.
} 
kinimu sistema yra paremta tapatybiniu intravertiškumu. Taigi įsitikinimai ir įsitikinimu sistemos įtvirtinimo procesas (prisiminimų ir politinių ịvykių emocionalizavimas, istorinès analogijos, stereotipizavimas ir pan.), kalbant Becko terminais, sudaro prielaidas formuoti permanentinę grèsmę jaučiančią visuomenę $e^{71}$.

Baimès ar kitokio pobūdžio ịsitikinimu sistemos formavimasis taip pat yra priklausomas nuo valstybės komunikacijos su kitomis valstybėmis intensyvumo. Kuo uždaresnè visuomené, tuo jos tapatumas labiau linkęs $\mathfrak{i}$ intravertiškumą ( $A$ š konstravimas Savęs nepririšant prie reikšmingų Kitų), tuo didesnè tikimybé, jog originalios, tik tai valstybei būdingos ịsitikinimu sistemos, bus tvirtos ir įtakingos užsienio politikoje ${ }^{72}$. Pavyzdžiui, Rusijos Federacijoje žiniasklaida labai priklausoma nuo valstybès, o pati valdžia paremta aiškios vertikalès egzistavimu. Tai savaime sudaro galimybes valstybès mastu legitimizuoti ịvairius mitus, stereotipus, kurie ne tik paaiškina, bet ir formuoja šalies užsienio politiką. Pavyzdžiui, tikejjimas priešiškais Vakarais, Baltijos valstybių fašizmu, Rusijos kaip pasaulio galios ir gelbètojos būtinumu.

Taigi baime paremtoms įsitikinimu sistemoms išorès aplinka ir joje vykstantys procesai nèra itin svarbūs. Išorès aplinka yra subordinuojama ịsitikinimu sistemos modeliui ir gali atlikti tiesiog patogaus simuliakro funkciją. Isitikinimu sistemos, paremtos grèsmès permanentine pajauta, susiformavimas labiau priklauso nuo bendruomeneje vyraujančių šališkų ịsitikinimų ${ }^{73}$ ir suvokimų, kurie iškreipia realybę bei galimybę rasti racionalų grèsmingos situacijos sprendimą (pavyzdžiui, Irvingo Janio, Leono Manno ${ }^{74}$, Richardo Nibetto ir Lee Rosso ${ }^{75}$ tyrimai). Robertas Jervis akcentuoja, jog, priešingai nei reikalautų racionalaus sprendimo modeliai, visuomenè neatnaujina informacijos vertindama ir suvokdama esamą situaciją, o dažnai remiasi anksčiau iggyta patirtimi ir žiniomis ${ }^{76}$.

Intravertiška tapatybe paremtos įsitikinimu sistemos susiformavimo

\footnotetext{
${ }^{71}$ Kadangi kitos valstybès gali turèti kitokias įsitikinimu sistemas (pavyzdžiui, kantiškajji - Ewiger Frieden), tokios autoriaus idejos veikiau oponuoja realistams, nei jiems pritaria.

${ }^{72}$ Tai patvirtina D. Rousseau atlikta analzè. Rousseau D., Identifying Threats and Threatining Identities: The Social Construction of Realism and Liberalism, Stanford University Press, 2006.

${ }^{73}$ Visuomene interpretuoja faktus apie galimas grèsmes savaip net tada, kai faktai nesudaro jokio pagrindo kalbèti apie potencialią grèsmę. Cramer J., Thrall T., Understanding threat inflation, American Foreign Policy and The Politics of Fear- Threat Inflation since 9/11 (eds.) Cramer J., Thrall T., 2009.

${ }^{74}$ Janis I., Mann, L., A psychological analysis of conflict, choice, and commitment. New York: Free Press, 1977.

${ }^{75}$ Nisbett R., Ross L., Human inference: Strategies and Shortcomings of Social Judgment, Englewood Cliffs, N.J.: Prentice-Hall, 1980.

${ }^{76}$ Jervis R., The Remaking of a Unipolar World, Washington Quarterly, Summer 2006.
} 
aiškinimui reikšmingų ižvalgų suteikia ir psichologinès krypties aiškinimo linijos šalininkai, teigiantys, jog psichologinis šališkumas, dèl kurio kyla grèsmių eskalavimas, yra lemiamas subjektų ịsitikinimui, jog jie veikia racionaliai. Tai gerai iliustruoja fundamentalios atribucijos klaidos konceptas $^{77}$, kuriame aiškinama, jog kai vienas žmogus stebi kitą, stebètojas linksta aiškinti kito elgseną pagal savo charakterị, prigimtį ir giliai ịsišaknijusius motyvus. Kartu stebėtojas linksta manyti, jog jo paties elgsena yra tik reakcija ị situaciją ir stebimojo veiksmus, niekaip nesusijusi su subjektyviomis charakterio, prigimties ar motyvų implikacijomis. Kitaip tariant, stebetojas yra linkęs manyti, kad stebimasis, pavyzdžiui, ginkluojasi todèl, jog yra iš prigimties priešiškas ir agresyvus. Ši situacija verčia lyderius ir visuomenę save pateisinti, save traktuojant kaip mažiau priešiškus, tik reaguojančius i situaciją.

Grèsmès suvokimą, paremtą ịsitikinimu sistema (pavyzdžiui, para bellum), galima suprasti kaip individualų, intravertiška tapatybe paremtą, todèl labai šališką aplinkos refleksijos procesą, kuriame informacijos apie aplinką ir jos procesus stygius kompensuojamas asmenine, istorine, emocine, kultūrine patirtimi. Kitaip tariant, aplinkos ir Kitu refleksijoje labai ryškus ir įtakingas yra Aš naratyvas (savęs įsivaizdavimas). Tad įsitikinimu sistemos sampratoje reiškiamos grèsmès priežastys yra daugiau vidinès ir tiesiogiai susietos su subjekto tapatybeje įsitvirtinusiais stereotipiniais modeliais ir jų emocionalia manifestacija, todèl tarptautinè aplinka (kaip objektyvi tikrovè) turi mažai potencialo paveikti, pakeisti grèsmès lygį ir intensyvumą. Tarptautiniai pokyčiai ir tarptautinių procesų dinamika iš esmès yra svarbi tik suaktyvinant pasyvius ar sukuriant naujus įsitikinimu sistemu leitmotyvus (pavyzdžiui, ko nors baimè), kurie vèliau konstruojami ir palaikomi išimtinai uždaroje valstybès tapatybinèje erdveje (žiūrèti 2 pav.)

\footnotetext{
${ }^{77}$ Kelley H., Michaela J., „Attribution Theory and Research“, Annual Review of Psychology, Vol. 31: 457$501,1980$.
} 


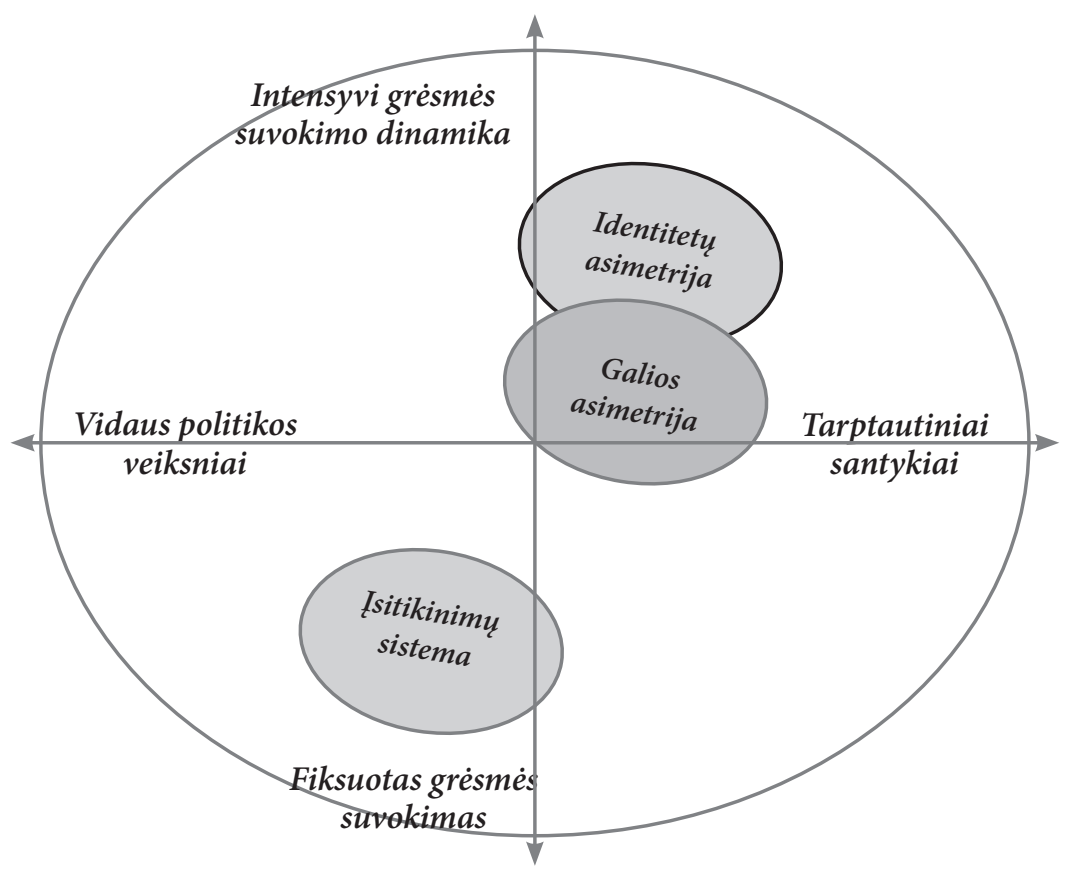

2 pav. Grèsmės suvokimo sampratų žemėlapis

Taigi grèsmès suvokimas ịsitikinimų sistemoje gali būti suprantamas kaip subjektyvus nusiteikimas, nusistatymas, įsitikinimas arba tiesiog tikejjimas, jog grèsmé egzistuoja. Tokia įsitikinimų sistema, ịsitvirtinusi užsienio politikos naratyvuose, gali tapti svarbia valstybès identiteto dalimi, kuriai nereikia paaiškinimo ir pagrindimo.

Tai kartu yra ir viena esminių priežasčių, skiriančiu ịsitikinimų sistemą nuo kitų aptartų dinamiškų galios bei identitetų asimetrijos modelių. [ૃsitikinimų sistemos varomoji jèga - stipri intravertiška tapatybè nèra būdinga nei galios, nei identitetų asimetrijoms. Todèl būtent tapatybinio pobūdžio (intravertiško arba ekstravertiško) atpažinimas leidžia nustatyti, ar konstruojant politinio subjekto baimę dominuoja ịsitikinimų sistemos, ar konkretūs asimetrijos modeliai. Kitaip tariant, galios asimetrijos ar konkretaus tapatumo baimè gali būti konkrečios isitikinimų sistemos esminis ramstis, tačiau tik intravertiško tipo tapatumuose minètos baimès bus suvokiamos kaip įsitikinimų sistemos pasekmès. Taigi šia prasme tiek realizmo, tiek liberalizmo atskiros idejos ar jų dominavimas intravertiškose tapatybinėse konstrukcijose gali būti ịsitikinimų sistemų statybinè medžiaga. Tad tapatybëje užkonservuotos idèjinès (liberalios ar realistinès) schemos, neturinčios pakankamo sąlyčio su socialiniais fenomenais išorèje, veikiau grèsmès pajautą konstruos kaip neracionalią ir galbūt realybei neadekvačią. 
Apibendrintai galima sakyti, jog šie grèsmès suvokimo modeliai yra vertingi analizuojant užsienio politikos procesus, ypač užsienio politikos tikslų, vizijų ar tapatybių konstravimą. Pavyzdžiui, jei baimės priežastis yra ịsitikinimu sistema, tai didelè tikimybè, jog baimès kultūra subordinuos užsienio politikos strategiją, kuri bus labai nelanksti, netalpi ir neatliepi aplinkai bei materialiems ir nematerialiems struktūriniams pokyčiams. Jei baimès priežastis - identiteto asimetrija, tai baimès intensyvumas bus tiesiogiai proporcingas tapatybiniams pokyčiams ${ }^{78}$. Kitaip tariant, atsiradus intencijai plèsti identitetus, įtraukiant grèsmingus Kitus, baimès lygis socialinejje struktūroje mažès. Jei baimès priežastis - galių asimetrija, priklausomai nuo galios (ekonominès, politinès, karinès, kultūrinès) asimetrijų dinamikos baimè varijuos (keisis baimès objektas, mastas, pobūdis), taigi pati baimé bus tiesiogiai susieta su priežastimi (galios disbalansas), o ne su išankstiniu nusistatymu ar tapatybine stratifikacija.

\section{Baimès emocija Lietuvos užsienio politikoje}

Lietuvos užsienio politikoje nuo nepriklausomybès atkūrimo tapo iprasta skirti Lietuvos užsienio politikos etapus. Pirmasis etapas apima laikotarpi nuo Lietuvos nepriklausomybès atkūrimo iki euroatlantinès narystès 2004 metais (Ieva Karpavičiūte dar prieš tai skiria suvereniteto ịtvirtinimo etapą 1990-1994 m..$^{79}$ ), antrasis nuo 2004 iki $2009 \mathrm{~m}$. pristatomas kaip ambicingu viziju raiškos etapas ir nuo 2009 m. prasidejęs pragmatiškos užsienio politikos plètojimo etapas. Toks Lietuvos užsienio politikos periodizavimas paremtas skirtinga užsienio politikos vizijų raiška, kurią nulèmé nacionalinio tapatumo paieškos procesas. Lietuvos integracijos ị euroatlantines struktūras periodu šalies siekis buvo labai aiškus ir konkretus - narystė NATO ir ES, o tapatybinis užsienio politikos dẻmuo siejamas su ,grịžimu ị Europą ${ }^{\text {"80 }}$. Po sékmingos integracijos ir oficialaus euroatlantinès erdvès veikejo statuso igijimo Lietuvos užsienio politikoje formuojamas poreikis surasti aiškią ir reikšmingą valstybės funkciją naujoje politinèje, ekonomineje, kultūrinejje ir saugumo aplinkoje. Šia šalies funkcija tampa ambicinga regiono lyderes, tarpcivilizacinio centro ideja,

\footnotetext{
${ }^{78}$ Čia galima pabrèžti, jog priklausomai nuo to kaip apsibrèšim tapatybę (tai vidinių ar išorinių reiškinių rezultatas) priklausys ir baimès aiškinimo perspektyva.

${ }^{79}$ Karpavičiūtė I., „Kaita ir nacionalinė tapatybė užsienio politikos studijose: Lietuvos atvejis“, Politikos mokslu almanachas 07/2013; 13(13).

${ }^{80}$ Miniotaite, G. „Lietuvos saugumo ir gynybos politika: raida ir perspektyvos“, Lietuvos metine strategine apžvalga 2006, p. 164.
} 
kuri, anot jos propoguotojų, turejo natūraliai sietis su lietuviškuoju tapatumu. Galiausiai nuo 2009 m. galima pastebèti šalies užsienio politikos kurso ir formuojamos tapatybės strategijos pokyčius: pasirenkamas reikšmingas regionas, su kuriuo tapatinamasi, akcentuojamas pragmatiškumo, specializacijos, užsienio politikos subalansavimo poreikis. Tačiau, straipsnio autoriaus nuomone, šis periodas trunka tik iki Krymo okupacijos 2014 m., po kurio Lietuvos užsienio politika dar kartą keičia vertybinę ir tapatybinę orientaciją, tam tikru lygiu grąžinant prieš tai buvusio (regiono lyderès) etapo idèjų turinị.

Kaip jau minèta, Lietuvos akademiniame diskurse Lietuvos užsienio politikos tikslų kaitos (nestabilumo?) dinamika analizuojama daugiausiai kaip tapatybès paieškos priežastis. Taigi ieškant ir nesurandant sau aiškios vietos Vakarų bendruomenejje užsienio politika it koks vejjarodis sukiojasi priklausomai nuo to, kaip interpretuojami ir suvokiami $A \check{s}$, Mes ir Kitas.

Tačiau Lietuvos užsienio politikos tyrimų darbuose mažai tirtos paskatos, kurios ne tik vertè koreguoti nacionalinio tapatumo suvokimą ( $A \check{s}$, Mes ir Kitas interpretaciją), bet ir užpildè siūlomos tapatybès turinị. Kitaip tariant, atlikti tyrimai labiau apsiribojo tradicinio, gana pasyvaus konstruktyvizmo logika, akcentuojant svarbiausius tapatybinius veiksnius, taip nuošalyje paliekant patị idejų formavimo ir realizavimo procesą. Taigi nors reikšmingi tapatybiniai Kiti Lietuvos užsienio politikos analizejje yra aiškiai apibrežti ir gana detaliai analizuoti, tačiau šių reikšmingų Kitų santykiavimo su lietuviškuoju tapatumu pobūdis, dinamika ir aktyvumo lygis nèra aiškiai ịvertinti. Tai savo ruožtu riboja tiek Lietuvos tapatumo, tiek šalies užsienio politikos supratimo ir aiškinimo potencialą nes stereotipizuoti lietuviškosios tapatybès naratyvai (pavyzdžiui, suvereniteto, integracijos) verčia aiškinti šalies užsienio politikos praktiką pagal šiuos fundamentalius idejjinius šablonus. Kita vertus, minèti reikšmingi Kiti dažniausiai matomi pasyvūs, todèl ir pristatomas santykis tarp lietuviškojo Aš ir Kitas dažniau primena nuotrauką, o ne siužetą ir intrigą turintị filmą. Dèl to kai kurie šalies užsienio politikos momentai ar kryptys yra sunkiai paaiškinami. Šiame straipsnyje siūloma šią aptartą problemą spręsti analizuojant, koks intravertǐ̌ka tapatybe paremtos baimés emocijos (darbe pristatyta prasme) vaidmuo reiškiant Lietuvos užsienio politikos tikslus.

Toliau darbe detaliau analizuojamas ambicingų vizijų periodas, kuriuo buvo suformuluoti regioninès lyderystės tikslai ir, kaip jau teigta, naujasis, su Krymo aneksija prasidejjęs Lietuvos užsienio politikos etapas.

Lietuvos kaip regiono lyderès vizijos siekis buvo „diplomatinėmis priemonemis užtikrinti tautos ir valstybès saugią ir demokratinę raidą naujų galimybių ir grèsmių akivaizdoje, pasinaudojant gerais Lietuvos dvišaliais santy- 
kiais, naryste NATO, Europos Sąjungoje ir kitose tarptautinėse organizacijose, ịtvirtinant Lietuvą kaip aktyvią ir gerbiamą šiuolaikinę valstybę ${ }^{\text {c81 }}$. Šio siekio igyvendinimo strategija buvo paremta užmoju formuoti Lietuvos, kaip patrauklaus tarpregioninio bendradarbiavimo centro, skleidžiančio euroatlantines vertybes, toleranciją ir bendradarbiavimo dvasią, jungiančio kultūras ir civilizacijas, vaidmenį ${ }^{82}$. Tai, anot šios užsienio politikos koncepcijos kūrèjų, leistų plètoti solidarumo ir geros kaimynystės principus, skatinti kultūrų ir civilizacijų dialogą $a^{83}$, kuriame Lietuvai tektų traukos centro, regionų ir civilizaciju jungties, pirmą kartą istorijoje suvienijančios Rytus ir Vakarus, Šiaurę ir Pietus ${ }^{84}$, vaidmuo.

Tačiau šiame kurtame užsienio politikos naratyve dažnai akcentuotas regioninis (ypač Rytų, Lenkijos) matmuo netampa Lietuvos tapatybès dalimi. Kitaip tariant, nei geografija, nei konkrečios vertybių erdvès nustatymas nèra konstruotos tapatybès pagrindas. Tai galima įžvelgti analizuojant Prezidento Valdo Adamkaus Lietuvos, kaip regiono lyderès, vaidmens sampratą.

Aktyvi, lyderiška Lietuvos politikos kryptis Prezidento metiniuose pranešimuose pirmiausia tiesiogiai susieta su aktyvia, o ne pasyvia užsienio politika. Siekiant kuo arčiau ES ir NATO pritraukti Ukrainą, Moldovą, Baltarusiją ir Pietų Kaukazą, Adamkus Lietuvą ragina formuoti ambicingą užsienio politikos darbotvarkę ir tapti tarpregioninio bendradarbiavimo traukos centru, jungtimi, regiono lydere, būti visaverčiais europiečiais, nelikti Europos pakraščiu. Tokią užsienio politikos realizaciją Prezidentas pristato ne tik kaip istorine galimybę, bet kaip istorinę misiją. Taigi Adamkus valstybès visavertiškumq sujungia su jos aktyvumu, todèl buvimas Europos pakraštyje ar auksine provincija turi akivaizdžiai neigiamą prasmę. Kita vertus, nepaliekama erdvés „kitokiai“ Lietuvos užsienio politikos vizijai - centriškumas ir lyderystė tarsi istorinẻ šalies misija neišvengiama, todèl būtina realizuoti. Tai tarsi ir paaiškintų, kodèl tiek Adamkaus, tiek kitose Lietuvos lyderystès būtinybę pristatančiuose šaltiniuose nẻra pateikiama aiškių prielaidų, leidžiančių išpildyti tokius ambicingus tikslus ${ }^{85}$.

Prezidento Valdo Adamkaus metiniuose pranešimuose istorinis, kultū-

\footnotetext{
${ }^{81}$ Lietuvos politinių partijų susitarimas dèl pagrindinių užsienio politikos tikslų ir uždavinių 2004-2008 metais, $2004 \mathrm{~m}$. spalio $5 \mathrm{~d}$.

${ }^{82}$ Lietuvos politinių partijų susitarimas dèl pagrindinių užsienio politikos tikslų ir uždavinių 2004-2008 metais, $2004 \mathrm{~m}$. spalio $5 \mathrm{~d}$.

${ }^{83}$ Paulauskas, A. Naujoji Lietuvos užsienio politika. Pranešimas, skaitytas TSPMI 2004 m. gegužès 24 d., http://paulauskas.president.lt/one.phtml?id=4994, 01012016.

${ }^{84}$ Ten pat.

${ }^{85}$ Vèlgi tam tikra išimtis būtų Lenkija, kurios istorinis ir kultūrinis artumas Lietuvai Prezidento buvo aptariamas kituose viešuose pasisakymuose.
} 
rinis ir galiausiai tapatybinis bendrumas ar tapatinimasis su kitomis „bendruomenèmis“ apskritai nefigūruoja kaip veiksniai, svarbūs Lietuvos užsienio politikos tikslų realizacijai. Lietuva, keliant ambicingus tikslus, nėra tapatinama su „kažkuo“ (pavyzdžiui, regionu). Veikiau teigiama, kad Lietuva turètų veikti kaip tarpregioninio bendradarbiavimo centras. Kitaip tariant, aiškiai nèra nuspręsta, kam Lietuva priklauso ar turètų priklausyti: Lietuva ịsivaizduojama tarp kažko (Rytų ir Vakarų, Šiaurès ir Pietų), o ne kažkur (Vakaruose, Šiaurèje, Rytuose). Tad, nepaisant siekio aktyviai dalyvauti regiono politikoje, Lietuvos užsienio politikos kuriama tapatybe yra labiau intravertiško pobūdžio. Intravertiškumas pirmiausia reiškiasi kaip tapatybės pozicija ignoruoti aplinkinius tapatumus. Prie jų ne tik neprisirišama, bet ir jų (aplinkinių tapatumų) suvokimas vyksta fundamentalios atribucijos klaidos atmosferos situacijoje, kai Kiti matomi per subjektyvią prizmę, o savi interesai regimi kaip objektyvūs, teisingi ir racionalūs. Tam tikra prasme tai primena Edvardo Saido pristatytą Rytų ir Vakarų sąveiką, kurioje Vakarams susikuriant Rytų ịvaizdị patys Rytai ir jų turinys ne tik nèra esminiai, bet ir apskritai nesvarbūs $s^{86}$. Kitaip tariant ne realus laikas ir erdvè ir jos procesai, bet išankstinè schema, simuliakras tokio pobūdžio situacijoje yra supančios tikrovès reprezentantas.

Todèl Adamkus kuria regiono traukos centro tapatumą, kurio naratyvo pamatinès „detalès“ (tapatybinès, geografinès, iš dalies vertybinès), kaip pastebèjo Gražina Miniotaitè, neegzistuoja ${ }^{87}$. Lietuva matoma tarsi vakuume, kaip „civilizacijų kryžkelë“, turinti tik funkcinį, šiek tiek mistinị tikslą - sujungti Rytus ir Vakarus, būti „civilizacijų raktas“, kokio dar iki tol nebuvo. Ši valstybès tapatybės atpažinimo logika Prezidento Valdo Adamkaus sampratoje tampa atspirtimi ir ir kuriant Lietuvos ir Europos Sajungos santykių perspektyvą. Savo metiniuose pranešimuose Adamkus ragina nebūti pasyviais europietiškų vertybių priemėjais. „Narystė Europos Sąungoje tapo nuosekliausiu, visos visuomenès paramą užsitikrinusiu valstybès politiniu ir ekonominiu projektu po Lietuvos nepriklausomybès atkūrimo. Tai istorinè galimybė ir geriausia prielaida siekti strateginių tikslų - gerovès ir saugumo. Juos pasieksime tik būdami iniciatyvūs Europos klubo nariai, o ne nuolankūs vykdytojai“" ${ }^{\text {"88 }}$. Taigi Adamkus, nors ir laiko narystę ES Lietuvos istorine galimybe ir akcentuoja ES praktikų ir vertybių perémimo svarbą, Lietuvos savarankiškumo, išskirtinumo ir aktyvumo išsaugojimą laiko ne ką mažiau svarbiu nacionaliniu siekiu. Tai

\footnotetext{
${ }^{86}$ Said E., Orientalizmas, Vilnius: Apostrofa, 2006.

${ }^{87}$ Miniotaitė G., „Europos normatyvinè galia“ ir Lietuvos užsienio politika“, Politologija, 2006/3 (43).

${ }^{88}$ Prezidento Valdo Adamkaus metinis pranešimas, 2006 m.
} 
aiškiai pagrindžia 2005 metų pranešime pateiktas teiginys, jog negali būti „ES integracijos bet kokia kaina" ${ }^{\text {"89 }}$.

Adamkaus pranešimuose atsiskleidžia gana uždara Prezidento tautinè valstybès samprata, kuri (tikètina) yra viena pagrindinių priežasčių, kodèl Lietuva nèra suvokiama kaip Europos Sąjungos dalis. Lietuvos kaip regioninès lyderès tapatumas lemia, kad yra Mes (lietuviai) ir Jie europiečiai. ES politika suprantama kaip Kito politika. Nèra užuominų apie europietišką Lietuvos tapatumą, Europos Sąjungai Lietuva ịsipareigoja tik vertybiškai, bet ne politiškai. Taigi Lietuvos ir ES santykiuose dominuoja suvereniteto naratyvas.

Žvelgiant ị šią regiono lyderès vizijos interpretaciją galima matyti, jog kertinis kurto tapatumo principas yra išskirtinumo, savarankiškumo, funkcionalumo, suprantamo kaip šalies aktyvumas, siekis. Nors šioje koncepcijoje galima surasti Rytų ir Rusijos grésminimo motyvų, tačiau jie nèra esminè lipdomoji Lietuvos kaip regiono centro medžiaga. Rusija neatmetama kaip potenciali partnerè, aktyvia lyderiška veikla Lietuva jai gali padèti „kuo sklandžiau ịsitraukti i europinius bendradarbiavimo procesus ${ }^{{ }^{\prime}{ }^{90}}$. Apskritai, tiek Lietuvos prezidentų pranešimuose, tiek Nacionalinio saugumo strategijose (2005 ir 2012 m.) Rusija nefigūruoja kaip aiškiai suvokta grèsmè, ji veikiau apibrěžiama kaip valstybè, esanti erdveje, kuri kelia tam tikrą susirūpinimą dèl jos neapibrěžtumo, neprognozuojamumo ir kitoniškumo (žiūrèti 2 lentelę). Kitaip tariant, Rusija susirūpinimą kelia ne todèl, jog yra ,grèsmè savaime“, bet todèl, jog yra neapibrèžtoje erdvėje. Šiame Lietuvos ir Rusijos santykių tarpsnyje lietuviškasis Rusijos kaip grèsmès įsivaizdavimas nèra fiksuotas. Grèsmè, jos lygis ir intensyvumas priklauso nuo aiškių pokyčių realybejje: grèsmè gali sumažèti, pavyzdžiui, teigiamai pasikeitus identitetų asimetrijai (Rusijai sparčiau artejjant link aiškios ir draugiškos vertybės struktūros) ar teigiamai pasikeitus galios asimetrijai. Todèl ateityje konstruktyvus bendradarbiavimas yra ne tik ịsivaizduojamas kaip imanomas (Rusijai ištrūkus iš grèsmingos erdvès), bet ir pageidaujamas (pavyzdžiui, 16 vyriausybès programoje akcentuota perkrovimo politika).

Visgi Lietuvos lyderès kurtame tapatume baimès pojūtis yra svarbus, tačiau jis kyla ne dèl Kito neapibrèžtumo ir kitoniškumo (Rytų, Rusijos), bet dèl nerimo valstybei, tautai likti periferijoje ir ịsitikinimo, jog tik didelis politinis aktyvumas ir valstybès lyderiavimas yra valstybès klestejimo ar net išlikimo sąlyga. Kitaip tariant, valstybès siekị lyderiauti reikètų suprasti kaip veiksmą, atliekamą dèl baimès likti mažam, silpnam, negirdimam ar atitolusiam nuo centro. Šia logika sekant baimè, o ne geopolitika, geoekonomika, geokultūra yra

\footnotetext{
${ }^{89}$ Prezidento Valdo Adamkaus metinis pranešimas, $2005 \mathrm{~m}$.

${ }^{90}$ Prezidento Valdo Adamkaus metinis pranešimas, $2005 \mathrm{~m}$.
} 
šios užsienio politikos vizijos stuburas. Tai, jog tikimybė mažajai valstybei likti maža ir, kaip teigè Artūras Paulauskas, sunkiai matoma pasaulio žemèlapyje $e^{91}$ gąsdina, yra iš esmès intravertiško tapatumo požymis. Tiek Artūras Paulausko, tiek Prezidento V. Adamkaus regioninio pirmavimo vizijose apskritai nefigūruoja objektyvių prielaidų, leidžiančių realizuoti tokį projektą, aptarimas. Priešingai, realybė yra tam tikra prasme neigiama. Valstybès mažumas nèra priimamas kaip objektyvi fizinè ir tapatybinè duotybè, tačiau suvokiamas kaip nepageidaujama, tačiau išsprendžiama problema. Čia net galima rasti sąsajų su Gintaro Beresnevičiaus intelektualine provokacija apie Lietuvos Didžiosios Kunigaikštystès „reanimaciją“, akcentuojančia, jog Lietuva, norèdama būti išgirsta Vakarų, neturi atsisakyti imperinių ambicijų, nes imperijos poreikis tautai yra tarsi vaistas nuo socialinių ir geopolitinių negalių, varyte varančių lietuvius ị dvasinę ir fizinę savidestrukciją ${ }^{92}$. Beresnevičiaus abstraktūs ir poetiški teiginiai, jog lietuviai gimę valdyti ir būti imperine tauta iš dalies primena aptariamos vizijos igyvendinimo aiškinimą, vaizdingai akcentuojant tautos kultūrinị ir istorinị išskirtinumą ar misionieriškumą ${ }^{93}$. Todèl nieko keisto, jei emocionaliai parašytas Beresnevičiaus kūrinys galëjo įkvẻpti naujosios užsienio politikos architektus sujungti du emocionalius naratyvus: šalies mažumo baimę su šlovinga LDK praeitimi ir jos „reanimaciją" suvokti kaip pirmojo naratyvo problemos sprendimą. Galbūt dèl to Lietuvos užsienio politikos tapatybinis pasakojimas yra parašytas meniškai, tarsi literatūrinis nuotykis, kurio autoriai per daug nesigilindami ị kitų veikèjų (regiono valstybių) charakterių pristatymus pagrindiniam veikejui (Lietuvai) suteikè išskirtines esamam laikui ir erdvei būtinas lyderio savybes.

Todèl remiantis anksčiau pristatytu baimės priežasčių aiškinimu galima sakyti, jog regiono lyderés tapatume baimès priežastys yra ne su aplinkos reagavimu susijusios galios ar identitetu asimetrijos, bet subjektyvi, savarankiška ir originali įsitikinimu sistema, nustatyta šalies politinio elito, subjektyviai idealizuojant šalies istoriją, kompleksuojant dèl galimo šalies nevisavertiškumo, mažumo ar pasyvumo galimybès. Trumpai tariant, Lietuvos lyderystès idėjos konstrukcijoje objektyvų aplinkos nustatymą keičia asmeninè, istorinè, emocinè, kultūrinè valstybės ir valstybės elito patirtis bei intencijos. Tai, viena vertus, kurtą valstybės tapatybę daro nenatūralią, nesąveikaujančią ir nederančią su

\footnotetext{
${ }^{91}$ Paulauskas A., Naujoji Lietuvos užsienio politika, pranešimas, skaitytas VU (Vilniaus universitete) 2004 m. gegužès 24 d., http://paulauskas.president.lt/one.phtml?id=4994,01 012016.

${ }_{92}$ Beresnevičius G. Imperijos darymas. Lietuviškos ideologijos metmenys, Vilnius, 2003.

${ }^{93}$ Taip pat galima priminti, jog $2008 \mathrm{~m}$. Lietuvos įvaizdžio programa buvo paremta šūkių - „Lietuva drąsi šalis“, kurios išskirtinumas pateikiamas pabrèžiant tai, jog ji paskutinė Europos pagonių tauta, kadaise išsiplètusi ị didžiulę valstybę ir inicijavusi Sovietų Sąungos imperijos žlugimą.
} 
aplinka, joje vykstančiais procesais ir objektyviais šalies parametrais, antra vertus, toks tapatybès internalizavimas valstybès viduje gali sukurti permanentini nepagrịstą nerimo, baimès, nepasitikejjimo jausmą, trukdantị konstruktyviai bendradarbiauti su užsienio politikos partneriais. Pavyzdžiui, Lietuvos pozicijos atmetimas ar neịsiklausimas ị ją gali būti traktuojamas kaip grèsmė nacionaliniam saugumui.

Prezidente tapus Daliai Grybauskaitei Valdo Adamkaus prezidentavimo sukonstruota Lietuvos regiono lyderès įsitikinimu sistema dekonstruojama. 2012 metų pranešime Grybauskaitè pabrěžia, jog Lietuvos interesai reikalauja kūrybiškos užsienio politikos ir išmanios diplomatijos: „Prioritetą teikiu ne ceremoniniams susitikimams ar iškilmingoms deklaracijoms, bet konstruktyviam dialogui ir vertybiniam interesų derinimui. “" ${ }^{94}$ Tai lyg ir savotiškas skatinimas atsitraukti nuo tik deklaratyvių užmojų ir atsisukti ị realius šalies interesus. Prezidente tai supranta kaip gilesnių, glaudesnių santykių su Baltijos valstybėmis ir Šiaurès šalimis palaikymą. Svarbiausi šios krypties elementai - tai regioninė partnerystè, regioninė vienybė, regioninès institucijos, Baltijos valstybių istorinis ir geopolitinis bendrumas, geroji Šiaurès šalių patirtis. Lietuva šioje kryptyje aiškiai pozicionuoja baltiškąji savo tapatumą, tapatinasi su Baltijos jūros regionu, Šiaurès šalių subregionu spręsdama saugumo, ES klausimus (ekstravertiš$k a$ tapatybè). Lietuva suvokiama kaip tarptautinès bendruomenès dalis, taigi valstybè nebèra tapatybiniame vakuume, o sunkiai apčiuopiamą istorinę misija keičia pragmatizmas (poreikis efektyviau veikti ES, aiški tapatybinè erdvè). Tai iš esmès yra pagrindiniai naujos užsienio politikos kurso tapatybiniai veiksniai ${ }^{95}$. Žinoma, tai, kas yra racionalūs šalies interesai yra gana reliatyvus klausimas. Tačiau naujas ekstravertiško tipo tapatybinis rakursas paremtas ne vien tik vidiniais įsitikinimais (Lietuva turi būti (yra) lyderè, centras, Lietuva negali būti maža, periferija), bet apima ir svarbius išorèje esančius niuansus - Lietuva yra viena iš trijų mažų Baltijos valstybių, Lietuvai svarbi šiaurietiška politinė, socialinè patirtis ir pan. Taigi konstruojant užsienio politikos identitetą atsiranda realus laikas ir erdve su daugybe kitų savarankiškai egzistuojančių svarbių tapatybinių kintamųjų.

Taip su Grybauskaite prasidèjęs naujas užsienio politikos etapas nebeturi pačiame naratyve užprogramuotų grèsmių ir baimių. Nerimas ar grèsmė naujai konstruotoje užsienio politikos tapatybèje veikiau reiškiasi identiteto asimetrijos principu - baimę kelia galimybė per daug atitolti nuo stabilumą

\footnotetext{
${ }^{94}$ Prezidentès Dalios Grybauskaitè metinis pranešimas, $2012 \mathrm{~m}$.

${ }^{95}$ Reikia pabrèžti, jog straipsnyje analizuojami tapatybiniai veiksniai, o ne jų praktinis realizavimas. Todèl, ar konstruota pragmatinè užsienio politikos vizija praktikoje buvo realizuota racionaliai, yra kitas klausimas.
} 
ir gerovę garantuojančių tapatybinių struktūrų - Europos Sąjungos ar Šiaurès šalių (tai gali būti suvokiama kaip ekonominis pragmatizmas ${ }^{96}$ ). Tai priešingas ankstesnei lyderyste paremtos tapatybės funkcijai veiksmas, nes ieškoma už ko užkibti, o ne tiesiog šokama ị tapatybinị vakuumą ịsivaizduojant save kaip išskirtinị ir ypatingą. Todèl kolektyvinè partnerystė (Šiaurès šalys, Baltijos valstybès) ir pragmatinis bendradarbiavimas (skambutis Rusijos prezidentui Dmitrijui Medvedevui, vizitų apsikeitimas su Baltarusijos prezidentu Aleksandru Lukašenka), o ne išskirtinumą laiduojanti lyderystẻ tampa Lietuvos užsienio politikos pagrindu.

Pragmatiniai santykiai su Rusija buvo ịmanomi, nes tapatybinėje Lietuvos užsienio politikos struktūroje vyravo Rusijos, kaip valstybės, esančios nedraugiškoje aplinkoje, naratyvas. Rusijos teigiama transformacija buvo ịsivaizduojama kaip tikètina. Todèl net nuo 2001 m. augant Rusijos ekonominei, politinei ir karinei galiai ar net ivvertinus atskirus Rusijos agresijos ir revizionistinius veiksmus (2008 m. karas su Gruzija, 2007 m. Rusijos pasitraukimas iš Iprastinès konvencinès ginkluotès apribojimo Europoje sutarties, kibernetinès ir informacinès atakos, energetinis šantažas, Rusijos nacionalinio saugumo strategija iki 2020 m., kurioje Vakarai apibréžiami kaip priešiški ir pavojingi) Rusija oficialiuose Lietuvos užsienio ir nacionalinio saugumo diskursuose netapo egzistencine ir prigimtine grèsme. Kaip minèta Lietuvos nacionalinio saugumo strategijose (2005 m., 2012 m.), vyriausybių programose ir Lietuvos prezidentų pranešimuose neatpažino tiesioginès karinès grèsmès Lietuvai. Priešingai, 16-osios vyriausybès programoje raginama Lietuvos ir Rusijos santykius grịsti neatsižvalgant i praeiti, juos perkraunant. Net Maskvos atžvilgiu visada griežtesnę poziciją turinčių konservatorių vyriausybės programoje Rusija taip pat nèra traktuojama kaip užprogramuota revizionistinè valstybè. Išimtimi galima laikyti atskirai Tẻvynès Sąungos išleistą Rusijos sulaikymo strategija, kuri atspindi veikiau partijos, o ne valstybẻs poziciją (žiūrèti 1 ir 2 lenteles).

\footnotetext{
${ }^{96}$ Tai iliustruoja D. Grybauskaitès kritiškas komentaras, jog lietuviai pasirašinèja sutartis su „ubagais“ (Rytų valstybės), o su sprendimus priimančiomis Vakarų valstybėmis konfliktuoja.
} 
1 lentelè. Lietuvos ir Rusijos santykių apibrèžimas XV ir XVI vyriausybių programose

\begin{tabular}{|l|l|l|}
\hline & XV vyriausybe் & XVI vyriausybé \\
\hline Bendradarbiavimo sritys & $\begin{array}{l}\text { Ekonomika, teisiniai, politiniai } \\
\text { aspektai }\end{array}$ & Ekonomika \\
\hline Rusijos grèsmès lygis & Nedidelis & Beveik nèra \\
\hline Santykiụ tolesnè plètotė & $\begin{array}{l}\text { Lygiateisiškumas, žalos atlygin- } \\
\text { imas, demokratizacija }\end{array}$ & „Perkrovimas“ \\
\hline Tikslai Rusijos atžvilgiu & Demokratizacija, europeizacija & $\begin{array}{l}\text { Glaudesni, racionale- } \\
\text { sni (ekonomiškesni) } \\
\text { santykiai }\end{array}$ \\
\hline
\end{tabular}

2 lentelè. Lietuvos ir Rusijos santykių apibrèžimas 2012 m. Lietuvos Nacionalinio saugumo strategijoje

\begin{tabular}{|c|c|}
\hline Santykių pobūdis & Pozityvus (itraukiant) \\
\hline $\begin{array}{l}\text { Intencijos Rusijos } \\
\text { atžvilgiu }\end{array}$ & $\begin{array}{l}\text { - Stiprinti tarpusavio pasitikèjimą saugumo srityse } \\
\text { - Skatinti bendradarbiavimą ekonomikoje, transporto branduolinès } \\
\text { energetikos srityse. }\end{array}$ \\
\hline Lietuvos siekiai & $\begin{array}{l}\text { - Skatinti abipusi pasitikẻjimą ir bendradarbiavimą } \\
\text { - Remti NATO ir Rusijos bendradarbiavimą } \\
\text { - Skatinti ES dalyvavimą Lietuvos ir Rusijos santykiuose } \\
\text { - Itraukti Kaliningradą i regioninès integracijos procesus } \\
\text { - Siekti didesnio skaidrumo ir reguliavimo dèl Rusijos turimų } \\
\text { branduolinių ginklų }\end{array}$ \\
\hline
\end{tabular}

Galima teigti, kad toks Rusijos grèsmès traktavimas daugiausia buvo paremtas identiteto asimetrijos principu. Nepaisant kartkartėmis pasikartojančiu Lietuvos ir Rusijos diplomatinių ar ekonominių konfliktų, tikèjimas, jog Rusijos teigiami pokyčiai yra įmanomi, pačią baimę darè tiesiogiai priklausomą esamam santykių pobūdžiui (baimè dinamiška ir yra išoreje). Kitaip tariant, vyravo tikèjimas, jog Rusija gali būti Vakarų bendruomenès dalis todèl vien dèl pragmatinių sumetimų verta su ja bendradarbiauti. Tai puikiai atspindi faktas, jog nuo $2001 \mathrm{~m}$. didejjančios Rusijos santykinès (politinès, ekonominès, 
karinès) galios grèsminimas galios asimetrijos pagrindu taip ir netapo dominuojančiu oficialiame užsienio politikos diskurse.

Žinoma, Rusijos, kaip amžinos Lietuvos priešès ir didžiausios grèsmės nacionaliniam saugumui naratyvas egzistavo nuo pat šalies nepriklausomybés paskelbimo. Ypač dalis dešiniojo Lietuvos politinio elito dažniausiai viešuosiuose diskursuose siūlydavo ị Rusiją žvelgti kaip ị blogio imperiją, potencialią okupantę ar geopolitinę konkurentę. Šie siūlymai kaip traktuoti Rusiją dažniausiai labai paprasti, sudaryti vos iš kelių tapatybinių kriterijų (dažniausiai sovietinè patirtis ir kitos istorinès nuoskaudos), todèl labai stabilūs, atsparūs kaitai ir ịvairių socialinių procesų (kultūra, ekonomika, religija, politika ir pan.) ịtakoms. Tačiau toks, dažnai istorinemmis nuoskaudomis ir emocine patirtimi paremtas grèsmès traktavimas iš esmès netapo dominuojančia šalies pozicija (net, kaip minèta, po agresyvių Rusijos veiksmų Gruzijos atžvilgiu 2008 m) ${ }^{97}$. Tiek oficialiuose, tiek viešuose diskursuose šį rakursą atsverdavo kitos Rusijos i̊sivaizdavimo perspektyvos, siūlančios įvairesnị Rusijos tapatybès struktūros suvokimą. Dažniausiai šie suvokiniai papildyti Rusijos kaip ekonominės partnerès, Rusijos kaip geografinès kaimynès ịvaizdžiais, kurie tam tikra prasme pristabde baimès Maskvai maksimizavimą bei stereotipizavimą.

Visgi 2014 m. Krymo aneksija suaktyvina minètus Lietuvos nacionalinio saugumo bei užsienio politikos naratyvuose egzistavusius baimės Rusijai elementus. Todèl Rusijos revizionizmas, regioninès ir globalios galios statuso siekis nesilaikant tarptautinės teisės normų tampa neatsiejama Rusijos bei Lietuvos (Vakarų) ir Rusijos istorinių, esamų ir būsimų santykių, ịsivaizdavimo dalimi. Kartu grèsmès ir baimès šaltinis perkeliamas iš abstrakčios svetimos Rytų erdvès ị pačią Rusiją, kaip konkretų politinị vienetą.

Rusijos ir Rusijos grèsmès įsivaizdavimo pokyčiai vyksta tiek oficialiuose, tiek viešuose diskursuose. Ir žiniasklaidoje, ir oficialių pareigūnų kalbose gausu emocingų epitetų, apibrèžiančių Rusiją (Prezidentė Grybauskaitė Rusiją ịvardija kaip teroristinę valstybę, užsienio reikalų ministras L. Linkevičius Rusiją palygino su nacistine Vokietija), pagrindiniuose Lietuvos žinių portaluose (naujienose, susijusiose su Rusija) vyrauja militarinè retorika, panika dèl Rusijos ekspansijos ị Baltijos valstybes, Vakarų pasyvumo. Viešojo diskurso informacinèse žinutėse dominuoja Rusijos, kaip neprognozuojamos valstybés, ịvaizdis. Šalis dažnai regima Putino, turinčio psichologinių sutrikimų, asmenyje. Rusiją vis dažniau imama traktuoti ne tik kaip

\footnotetext{
${ }^{97}$ Ankstesniuose Lietuvos užsienio politikos tapatumuose (regiono lyderè, „pragmatiška regioninè politika“) Rusijos, kaip geopolitinio, istorinio, kultūininio, ekonominio subjekto, veiksnys nors ir būdavo svarbus, tačiau, kaip jau minèta, niekuomet esminis.
} 
SSRS teisių perėmėją, bet ir kaip jos vykdytos antagonistinès politikos Vakarų civilizacijos atžvilgiu tęseją̧. Taip pat dalis sunkiai kontroliuojamų problemų (bègliai iš Šiaurinès Afrikos ir Artimųjų Rytų, ISIS teroristinès atakos) viešojoje spaudoje regimos kaip tam tikros Maskvos iššauktos arba bent jau paremtos.

Gausu žinučių, kuriose Rusija suvokiama kaip kultūros ir ekonomikos barbaras, ne tik neatitinkantis Vakarų vertybių standartų, bet savyje laikantis regresyvią socialinę struktūrą (bei siekiantis ją primesti kitiems), ekonomiką naudojantis kaip politinị ịankị. Galima net pastebėti ịdomių vertybių poslinkių visos rusų tautos atžvilgiu. Jei anksčiau buvo ịprasta pabrèžti, jog rusų valdžia (Kremlius) yra „kenkejiška“, bet ne patys rusai (tauta), tai po Krymo aneksijos lietuviškoje žiniasklaidoje aptariant aukštus Vladimiro Putino populiarumo reitingus, vis dažniau pasigirsdavo savotiški siūlymai revizuoti ši suvokimą, tarp „Putino“ ir „rusų visuomenès“ ištrinant iki tol pastarąją saugojusią aiškią vertybinę liniją. Kitaip tariant rusų visuomenè tampa taip pat kalta ir yra sutapatinama ir matoma vieno simbolio (blogo Putino) kontekste. Galiausiai gimsta Rusijos kaip istorinès Lietuvos (ir Vakarų) kaip priešès iš prigimties įvaizdis.

Šios retorinès formos patenka ir ị oficialųji Lietuvos užsienio politikos diskursą. Pavyzdžiui, Prezidentès retorikoje galima aptikti žinučių, nurodančių, jog griežta reakcija ị Rusijos veiksmus yra būtina, nes Maskva išbando Vakarus ir, jei niekas jos nesustabdys, Rusijos ekspansija plèsis toliau ị Europą („Vladimiras Putinas eis tiek toli, kiek leis mūsų dvejonès ir nesitraukiantis naivumas"). Šiame kontekste grąžinama ir išskirtine Lietuvos misija - parodyti Vakarams ekspansinius Rusijos ketinimus. 2015 m. Grybauskaitès pranešime pabrèžiamas Lietuvos kaip lyderiaujančios kovoje su grèsme iš Rytų, ịvaizdis: „<...> drąsi ir nuosekli Lietuvos laikysena šioje kovoje (su „Gazprom") padès užtikrinti viso regiono energetinị saugumą, $<\ldots$. “; „<...> ịtikinome Europos Vadovų Tarybą, kad dezinformacija nuodija visų europiečių protus. ${ }^{\text {"98 }}$ Kitaip tariant, Rusija tampa grèsme, kuri visada kẻlè, kelia ir kels egzistencini pavojų Lietuvai ir Vakarams. Tai puikiai pagrindžia Lietuvos politinių partijų susitarimas „Dèl 2014-2020 metų Lietuvos Respublikos užsienio, saugumo ir gynybos politikos strateginių gairių “ (2014 m. kovo 29 d.), kuriame pabrèžiama, jog Rusijos revizionizmas regione yra ilgametis Maskvos tikslas, ekonominis bendradarbiavimas su Rusija kelia iššūkius nacionaliniam saugumui, Rusija iškraipo istoriją ir kelia grèsmę NATO ir ES valstybių saugumui. Kitaip tariant, palyginti su ankstesniu Rusijos įsivaizda-

${ }^{98}$ Prezidentès Dalios Grybauskaitès metinis pranešimas, $2015 \mathrm{~m}$. 
vimu, atmetama Rusijos grèsmès kaitos galimybè. Tokiu būdu Rusijos baimé, tikejjimas konflikto neišvengiamumu (Rusija anksčiau ar vèliau užpuls Lietuvą) ar Rusijos atsivertimu tampa esminiu dvišalių ar daugiašalių santykių principu. Tai, atsižvelgiant $\mathfrak{i}$ anksčiau išdèstytą samprotavimą, galima traktuoti kaip Lietuvos užsienio politikoje ịsitvirtinusią Rusijos baime paremtą bei para bellum principui artimą įsitikinimu sistemą, kuri dèl savo turinio (Rusijos klausimas tampa esminis ne tik Lietuvos saugumui, bet ir Lietuvos egzistencijai apskritai) ateityje natūraliai gali tapti lietuviškojo tapatumo leitmotyvu.

Jau dabar galima pastebėti, jog para bellum naratyvas po truputi įsitvirtina ir išstumia kurtą pozityviąją Lietuvos užsienio politikos viziją (integracija, pragmatizmas, strategija), turèjusią priartinti Lietuvą prie Vakarų standartų, vietą užleidžiant tiesiog negatyviam reagavimui ị ịvykius (ypač susijusius su Rusijos politika). Baimès emocija, kaip ir Lietuvos regiono lyderès koncepcijoje, rizikuoja tapti valstybės užsienio politikos vizijos stuburu, darančiu ịtaką ne tik dvišalių santykių (Lietuvos ir Rusijos), bet ir Lietuvos tapatybès, jos vietos ir funkcijų regione ${ }^{99}$ ir tarptautinių procesų priežasčių ${ }^{100}$ ịsivaizdavimui. Ši koncepcija nuo kitų skiriasi išimtinai savo emocionaliu performatyvumu. Tai, viena vertus, šią viziją daro artimą ir patrauklią viešajai erdvei, antra vertus, emocionalios retorinès formos, apeliavimas ne tik $\mathfrak{i}$ su vertybėmis susijusius jausmus, bet ir $\mathfrak{i}$ visuomenès psichologiją, spartina vizijos legitimizavima ir ịtvirtinimą šalies užsienio politikos diskurse. Šios koncepcijos įsitvirtinimo Lietuvos užsienio politikos diskurse atveju rizikuojama, jog Lietuvos siekiai, tikslai ir galiausiai konstruojama tapatybè, keičiantis tarptautinès politikos realijoms, nesugebės tinkamai prisitaikyti, todèl šalies užsienio politika bus neoptimali ir galbūt konfliktuojanti su Vakarų valstybių užsienio politikos strategijomis. Tai galima paaiškinti kaip para bellum vizijoje dominuojančių emocijų ir intravertiškų tapatybinių naratyvų raiškos valstybès politiokoje priežastį. Šiame kontekste Lietuvos regiono lyderès ideja labai koreliuoja su aptariama para bellum koncepcija (žiūrèti 3 pav.).

\footnotetext{
${ }^{99}$ Pavyzdžiui, Lietuva save mato kaip valstybę, priešakinèse linijose kovojančią su Rusija. ${ }^{100}$ Pavyzdžiui, Lietuvos politikų bei žiniasklaidos priemonių buvo analizuojama, kiek ir kaip Rusija prisidèjo aštrinant bèglių iš Sirijos, Libijos, Irako problemą.
} 


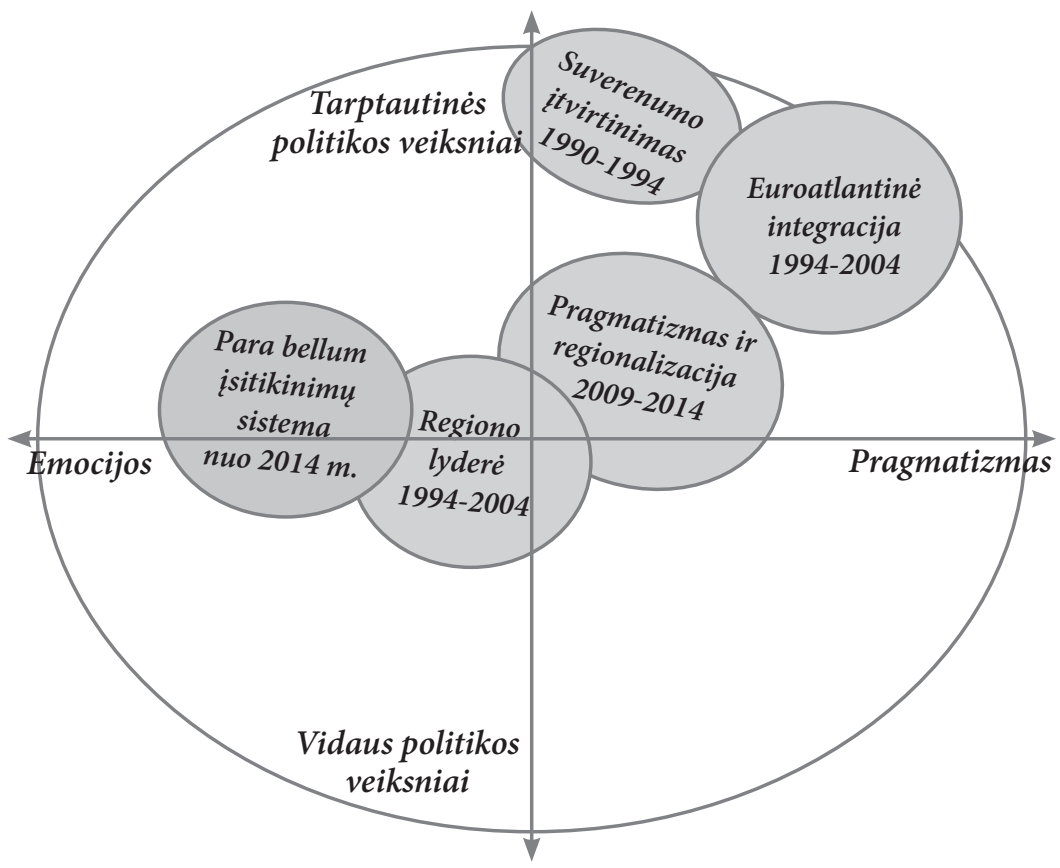

3 pav. Lietuvos užsienio politikos vizijų žemėlapis

Žinoma, teigti, jog para bellum užsienio politikos naratyvo atsiradimą labiausiai lèmé vidaus politikos veiksniai ir emocijos, nèra visiškai tikslu. Para bellum įsitikinimų sistemos įtvirtinimui užsienio politikos diskursuose lemiamos reikšmès turejjo išoriniai, regioniniai procesai - Rusijos agresija prieš Ukrainą. Galima sakyti, jog būtent baimès kultūros vyravimas Rusijos užsienio politikos diskurse buvo pagrindinè konflikto (Rusijos ir Ukrainos, Rusijos ir Vakarų) priežastis. Rusijos oficialiuose ir viešuose diskursuose tikèjimas valstybès išskirtine misija, nuolatinès baimès dèl savo išlikimo jautimas, statuso, o ne saugumo siekimas ${ }^{101}$ Maskvos užsienio politikos formavimą ir ígyvendinimą subordinavo emocionaliomis, baime grịstomis, ̣̦sitikinimų schemomis. Taigi Lietuvos nerimas ir baimé dèl Rusijos vykdytos agresijos yra pagrịstas, tačiau baimès eskalavimas vadovaujantis para bellum principu baimę daro savarankišką, save kuriančią ir mažai priklausomą nuo tolesnès ịvykių eigos. Kitaip tariant, baime paremtos įsitikinimu sistemos vyravimas Lietuvos užsienio politikos tapatybèje ateityje gali iggauti neadekvatų realybei mastą.

\footnotetext{
${ }^{101}$ Laurinavičius Č., Motieka E., Statkus N., Baltijos valstybiu geopolitikos bruožai: XX amžius. Vilnius: Lietuvos istorijos instituto leidykla, 2005, p. 313-314.
} 
Išvados

Straipsnyje aptarti nauji užsienio politikos analizės rakursai. Darbe pristatyta destrukciné baimès samprata reflektuoja tarptautinių santykių ir užsienio politikose įsitvirtinusią baimès kaip racionalų elgeș̣ skatinančios paskatos sampratą. Straipsnyje nèra ginčijama realistų ir liberalų tezè, jog baimė yra racionali. Veikiau parodoma, jog baimè gali turèti ir iracionalų, stereotipais, subjektyviais, nuo aplinkos atsietais įsitikinimais ir emocijomis (kaip manifestacinèmis praktikomis) grịstą pobūdị. Svarbiausias kriterijus nustatant baimès lygị pagal racionalumo ir iracionalumo skalę yra sąveika su aplinka. Baimès kaip racionalios paskatos atveju baimès objektas visada yra išorejje arba sukeltas Kito. Taigi baimès intensyvumo lygis yra tiesiogiai priklausomas nuo išorès ar Kito pokyčių (ekstravertiška tapatybè). Todèl apibrěžtos grèsmès ịsivaizdavimai, kaip galios ar identitetu asimetrija, yra racionalios baimės pavyzdys. Baime, kaip įsitikinimu sistemos priežastis, yra neracionali ir destrukcinio pobūdžio, nes pati baime (nors ir sukelta realaus baimès objekto) yra tiesiogiai priklausoma nuo valstybès viduje (intravertiškame tapatume) reiškiamos kognityvinès schemos. Taigi šiame modelyje valstybės baimès ịsivaizdavimas yra iš esmès nesusijęs su baimès objektu ir tarptautine aplinka. Emocijos šiame modelyje veikia kaip vienas esminių įsitikinimu sistema legitimizuojančiu veiksnių, todèl, teigiama straipsnyje, suvokti baimę kaip emociją - reiškia deracionalizuoti baimès fenomeną. Darbe išskirtos, skirtingomis tarptautinių santykių paradigmomis paremtos trys baimès sampratos nèra atskiri baimès suvokimo aiškinimai. Tai veikiau idealūs baimès suvokimo tipai, vienas kitą keičiantys ir papildantys realybejje.

Straipsnyje pateikta Lietuvos užsienio politikos vizijų analizė remiantis pristatytomis teorinemis įžvalgomis rodo, jog po $2014 \mathrm{~m}$. Krymo aneksijos galima kalbèti apie naujai besiformuojanti Lietuvos užsienio politikos etapą - para bellum. Jis darbe apibrèžtas kaip issitikinimu sistema, paremta egzistencine Rusijos baime. Nors Rusijos grèsmės naratyvas nuo pat nepriklausomybès atkūrimo figūravo Lietuvos užsienio politikoje, tačiau oficialiame diskurse jis neigaudavo egzistencinio pobūdžio. Net Rusijos grèsmès suvokimo suintensyvèjimo etapais - grèsmės objektas (Rusija) likdavo išoreje, t. y. grėsmés lygis likdavo priklausomas nuo Rusijos pokyčių dinamikos. Taigi Lietuvos diskurse įsitvirtinanti Rusijos baimè yra emocinio, todèl neracionalaus, aplinkai neatliepaus pobūdžio. Šis prasidejęs etapas savo idejine struktūra labai artimas Lietuvos regiono lyderés vizijai, kurioje baimès emocija reiškèsi kaip baimè likti periferijoje. 